\title{
EKSISTENSI LEMBAGA NEGARA DALAM PENEGAKAN HAK ASASI MANUSIA DI INDONESIA
}

\section{Existence of State Institutions in the Enforcement of Human Rights in Indonesia}

\author{
Muhammad Amin Putra \\ Fakultas Hukum, Universitas Indonesia \\ email: muhammadaminputra@gmail.com
}

\begin{abstract}
In the framework of the protection and enforcement of Human Rights by state institutions among implemented by: National Commission on Human Rights, Indonesian Child Protection Commission, National Commission for Women, the Truth and Reconciliation Commission, but the Truth and Reconciliation Commission in its development, it was disbanded because it does not correspond to the actual functions and duties so it does not give justice to the community. Besides carried out by the Commission, established by the State, protection and enforcement of Human Rights today is mostly done by the judiciary, especially after the reform. Among them are: the Specific Human Rights court, severe Human Rights court and the Constitutional Court who has the authority to test Legislations on the Constitution 1945. In the development, the Constitutional Court more precisely to the protection and enforcement of Human Rights to the citizens with the many rulings on the legislation is unconstitutional, and the Constitutional Court's decision was a strategic value and is able to uphold Human Rights for citizens. The essence of the protection and enforcement of Human Rights greatly influenced the position of the judge in deciding the case, so the judge has a role to uphold the independence and impartiality both as an institution and as individuals. Besides other factor is their right to receive legal aid, the pattern of justice has shown that the right to get a legal assistance is an attempt for equality in law as part of the fulfillment of Human Rights.
\end{abstract}

Keywords: State Institutions, Human Rights, Enforcement

\section{abstrak}

Dalam rangka perlindungan dan penegakan HAM oleh lembaga-lembaga Negara di antara dilaksanakan oleh: Komisi Nasional Hak Asasi Manusia (Komnas HAM), Komisi Perlindungan Anak Indonesia (KPAI), Komisi Nasional Perempuan (Komnas Perempuan), Komisi Kebenaran dan Rekonsiliasi (KKR), namun dalam perkembangannya KKR justru 
dibubarkan karena tidak sesuai dengan fungsi dan tugasnya yang sesungguhnya sehingga tidak memberikan keadilan pada masyarakat. Selain dilakukan oleh Komisi yang dibentuk oleh Negara, perlindungan dan penegakan HAM saat ini lebih banyak dilakukan oleh lembaga peradilan, khususnya pasca reformasi. Diantaranya yaitu: Pengadilan HAM khusus peradilan HAM berat dan Mahkamah Konstitusi (MK) yang memiliki kewenangan menguji UU atas UUD 1945. Dalam perkembangannya justru MK lebih banyak melakukan perlindungan dan penegakan HAM pada warga Negara dengan banyaknya putusan-putusan terhadap undang-undang yang inkonstitusional, dan putusan MK pun bernilai strategis dan mampu menegakkan HAM bagi warga Negara. Esensi perlindungan dan penegakan HAM tersebut sangat dipengaruhi kedudukan hakim dalam memutus perkara, sehingga hakim memiliki peran dalam menegakkan independensi dan imparsialitas baik sebagai institusi maupun sebagai individu. Selain itu faktor lainnya adalah adanya hak mendapat bantuan hukum, pola penegakan keadilan telah menunjukkan bahwa hak untuk mendapatkan bantuan hukum adalah upaya adanya persamaan dalam hukum sebagai bagian dari pemenuhan akan hak asasi manusia.

\section{Kata Kunci: Lembaga Negara, Hak Asasi Manusia, dan Penegakan}

\section{A. Pendahuluan}

Sejarah ketatanegaraan Indonesia telah mengamanatkan pada lembaga-lembaga negara untuk menegaskan perlindungan dan penegakan hak asasi manusia. Dalam rentang waktu sebelum dilakukan perubahan UUD 1945, perlindungan HAM belum menjadi isu dan pemahaman umum. Hal ini tidak terlepas dari suasana politik dan kehidupan bernegara yang bernuansa represif.

Salah satu perubahan yang dilakukan pasca amandemen UUD adalah semakin besarnya perhatian masyarkat dan pemegang kekuasaan untuk menegaskan dan menegakkan HAM di Indonesia. Dengan diatur secara komprehensif dalam UUD 1945 mengenai HAM dalam Pasal 28, dan 28A28J serta disahkannya UU Nomor 39 Tahun 1999 tentang Hak Asasi Manusia, UU Nomor 26 Tahun 2000 tentang Pengadilan HAM, bahkan mengenai informasi publik diatur dalam UU Nomor 14 Tahun 2008 tentang Keterbukaan Informasi Publik, telah menjadi landasan agar perlindungan HAM harus ditegakkan oleh semua insan negara. Salah satunya oleh lembaga-lembaga negara, tidak dapat dipungkiri bahwa perkembangan lembaga negara Indonesia memberikan nilai positif dalam penegakan HAM.

Dengan amanat UUD 1945 terhadap perlindungan HAM, tidak menjadi jaminan hak asasi akan langsung terlindungi dan ditegakkan, namun diperlukannya peran serta dan campur tangan negara khususnya pemerintah. 
Penegakan HAM pada dasarnya tidak hanya menjadi kewajiban lembagalembaga eksekutif (pemerintah) sebagaimana amanat Pasal 28I ayat (4) selaku pelaksana penyelengaraan negara paling depan. Namun, implikasi atas perubahan UUD 1945 telah melahirkan lembaga-lembaga yang bersifat Ad $\operatorname{Hoc}^{l}$ yang dibentuk dengan undang-undang dan lembaga-lembaga peradilan yang berperan signifikan dalam penegakan HAM di Indonesia. Di samping itu dalam perkembangan saat ini, lembaga peradilan dalam praktik sering melakukan penegakan HAM. Beberapa putusan peradilan diantaranya dalam permohonan uji materi undang-undang di Mahkamah konstitusi salah satunya menjadi perkembangan kontemporer yang menjadi gerbang perlindungan HAM.

Jenis penelitian dalam penulisan hukum ini adalah penelitian hukum normatif atau penelitian hukum kepustakaan. Penelitian ini mencakup penelitian terhadap asas-asas hukum, penelitian terhadap sistematika hukum, penelitian terhadap taraf sinkronisasi vertikal dan horizontal, perbandingan hukum dan sejarah hukum. ${ }^{2}$. Pendekatan dalam penelitian hukum terdapat beberapa pendekatan, yaitu pendekatan perundang-undangan (statute approach), pendekatan kasus (case approach), pendekatan historis (historical approach), pendekatan perbandingan (comparative approach) dan pendekatan konseptual (conceptual approach). ${ }^{3}$ Pendekatan penelitian yang digunakan adalah pendekatan historis dan konseptual.

\section{B. Pembahasan}

\section{Lembaga Negara Penegak HAM \\ a. Komnas HAM}

Penegakan HAM di Indonesia, terjadi ketika muncul Keputusan Presiden (Keppres) RI Nomor 129 Tahun 1998 tentang Rencana Aksi Nasional Hak-hak Asasi Manusia Indonesia 1998-2003 ${ }^{4}$ dalam rangka menegakkan HAM dengan dasar segala ketentuan aturan hukum ${ }^{5}$. Hal ini

\footnotetext{
${ }^{1}$ Dalam Black's Law Dictionary, ad hoc artinya: formed for a particular purpose (Latin).

${ }^{2}$ Soerjono Soekanto dan Sri Mahmudji, Penelitian Hukum Normatif: Suatu Tinjauan Singkat, (Jakarta: CV. Rajawali, 1985), hlm 34-35 dan 41.

${ }^{3}$ Peter Mahmud Marzuki. Penelitian Hukum, (Jakarta: Kencana, 2006), hlm. 93.

4 Ditandatangani oleh Presiden B.J. Habibie dan dilakukan secara bertahap dan berkesinambungan dalam suatu program 5 (lima) tahunan yang akan ditinjau dan disempurnakan setiap 5 (lima) tahun, lihat Pasal 1 ayat (3).

${ }^{5}$ Lihat klausul Menimbang

a.bahwa bangsa Indonesia sebagai bagian dari masyarakat internasional menghormati, menghargai dan menjunjung tinggi prinsip-prinsip dan tujuan-tujuan Piagam Perserikatan Bangsa-Bangsa serta Deklarasi Universal mengenai Hak-hak Asasi Manusia;

b.bahwa Deklarasi dan Program Aksi di bidang Hak-hak Asasi Manusia (Vienna Declaration and Programme of Action of the World Conference on Human Rights) telah
} 
didasari bahwa negara memiliki kewajiban-kewajiban untuk menghargai hak asasi orang lain di setiap tempat serta untuk melindungi dan menegakkan hak asasi warga Negara di wilayah mereka ${ }^{6}$.

Karena selama 32 tahun rezim orde baru, hak asasi manusia tidak ditegakkan dan banyak munculnya pelanggaran HAM yang justru dilakukan oleh negara. Dalam ketentuan Keppres tersebut ditegaskan empat pilar utama pembangunan HAM di Indonesia sebagai berikut: (1) persiapan pengesahan perangkat-perangkat internasional $\mathrm{HAM}^{7}$; (2) diseminasi dan pendidikan $\mathrm{HAM}^{8}$; (3) pelaksanaan HAM yang ditetapkan sebagai prioritas'; dan (4) pelaksanaan isi atau ketentuan-ketentuan berbagai perangkat internasional HAM yang telah disahkan Indonesia ${ }^{10}$.

Sebagai implementasi dari keppres yang dikeluarkan oleh Presiden B.J Habibie saat itu, maka diberlakukannya UU No. 5 Tahun 1998 tentang Pengesahan Convention Againts Torture and Other Cruel, Inhuman, or Degrading Treatment or Punishment ${ }^{11}$, dan diikuti dengan Ketetapan MPR Nomor XVII/MPR/1998 tentang HAM. Langkah konkrit kemudian adalah dibentuknya Komisi Nasional Hak Asasi Manusia (Komnas HAM) yang sebelumnya telah diamanatkan untuk membentuk lembaga tersebut ${ }^{12}$. Pembentukan Komnas HAM diundangkan dalam UU No. 39 Tahun 1999

diterima pada Konferensi Dunia kedua mengenai Hak-hak Asasi Manusia di Wina, Austria pada tanggal 25 Juni 1993;

c.bahwa penghormatan atas hak-hak asasi manusia telah dijamin oleh Pancasila dan Undang-Undang Dasar 1945 yang merupakan pandangan hidup, falsafah bangsa dan landasan konstitusional bagi Negara Kesatuan Republik Indonesia;

d.bahwa pelaksanaan hak-hak asasi manusia di Indonesia perlu mempertimbangkan nilainilai adat istiadat, budaya, agama dan tradisi bangsa serta tanpa membeda-bedakan suku, ras, agama dan golongan;

e.bahwa peningkatan pemajuan dan perlindungan hak-hak asasi manusia mendorong tercapainya tujuan pembangunan nasional, yaitu pembangunan manusia seutuhnya dan pembangunan masyarakat seluruhnya; dan

f. bahwa untuk lebih menjamin upaya pemajuan dan perlindungan hak-hak asasi manusia sesuai dengan dinamika perkembangan dan kebutuhan masyarakat Indonesia, dipandang perlu menyusun Rencana Aksi Nasional Hak-hak Asasi Manusia Indonesia dengan Keputusan Presiden.

${ }^{6}$ James W. Nickel, Hak Asasi Manusia, Making Sense of Human Rights, (Jakarta: PT Gramedia Pustaka Utama, 1996), hlm. 61.

${ }^{7}$ Lihat Pasal 2 huruf a (Keppres) RI Nomor 129 Tahun 1998.

${ }^{8}$ Lihat Pasal 2 huruf b (Keppres) RI Nomor 129 Tahun 1998.

${ }^{9}$ Lihat Pasal 2 huruf c (Keppres) RI Nomor 129 Tahun 1998.

${ }^{10}$ Satya Arinanto, Hak Asasi Manusia Dalam Transisi Politik di Indonesia, (Jakarta: Pusat Studi Hukum Tata Negara Fakultas Hukum Universitas Indonesia, 2008), hlm. 6.

11 Konvensi Menentang Penyiksaan dan Perlakuan atau Penghukuman Lain yang Kejam, Tidak Manusiawi, atau Merendahkan Martabat Manusia, LN Nomor 164 Tahun 1998, TLN Nomor 3783.

${ }^{12}$ Lihat Pasal 4 Ketetapan MPR Nomor XVII/MPR/1998 tentang HAM. 
tentang Hak Asasi Manusia (HAM) ${ }^{13}$. Dengan diundangkannya UU HAM telah mengamanatkan Negara khususnya pemerintah untuk perlindungan, pemajuan, penegakkan, dan pemenuhan HAM warga negaranya ${ }^{14}$.

Dalam UU HAM juga telah menentukan adanya sebuah lembaga yang mengurusi masalah HAM, yaitu Komisi Nasional Hak Asasi Manusia (Komnas HAM). Keberadaan Komnas HAM berdasarkan ketentuan dalam Pasal 1 angka $7^{15}$, dan memiliki fungsi diantaranya fungsi pengajian, penelitian, penyuluhan, pemantauan, dan mediasi tentang $\mathrm{HAM}^{16}$. Saat ini Komnas HAM memiliki eksistensi yang signifikan dalam memberikan edukasi dan pemahaman HAM terhadap masyarakat. Berdasarkan data yang dihimpun oleh Komnas HAM pada bulan Februari tahun 2013 menunjukkan bahwa eksistensinya semakin dibutuhkan oleh warga Negara, diantaranya:

Tabel $1^{17}$

Distribusi Berkas Pengaduan

\begin{tabular}{|c|l|c|}
\hline No & \multicolumn{1}{|c|}{ Subkomisi } & Jumlah \\
\hline 1 & Subkomisi Pemantauan dan Penyelidikan & 383 \\
\hline 2 & Subkomisi Mediasi & 10 \\
\hline \multicolumn{2}{|r}{ Jumlah } & $\mathbf{3 9 3}$ \\
\hline
\end{tabular}

Dengan banyaknya aduan yang diajukan masyarakat maka, keberadaan Komnas HAM cukup memberikan kesadaran serta munculnya kenyamanan pada masyarakat serta terlaksananya HAM yang merupakan salah satu tujuan Komnas HAM $^{18}$. Khususnya pada lapisan masyarakat yang rentan terhadap pelanggaran HAM.

\footnotetext{
${ }^{13}$ UU No. 39 Tahun 1999 tentang HAM LN Nomor 165 Tahun 1999 dan TLN Nomor 3886.

${ }^{14}$ Pasal 2 UU No. 39 Tahun 1999 tentang HAM.

15 Komisi Nasional Hak Asasi Manusia yang selanjutnya disebut Komnas HAM adalah lembaga mandiri yang kedudukannya setingkat dengan lembaga negara lainnya yang berfungsi melaksanakan pengkajian, penelitian, penyuluhan, pemantauan, dan mediasi hak asasi manusia.

${ }^{16}$ Lihat Pasal 76 ayat (1) UU No. 39 Tahun 1999 tentang HAM.

${ }^{17}$ www.komnasham.org diakses pada 3 april 2015, pkl.13:17.

${ }^{18}$ Lihat Pasal 75 UU No. 39 Tahun 1999 tentang HAM.
} 
Tabel $2^{19}$

Klasifikasi Hak ${ }^{20}$

\begin{tabular}{|c|l|l|}
\hline No & \multicolumn{1}{|c|}{ Klasifikasi Hak } & Jumlah \\
\hline 1 & Hak untuk hidup & 17 \\
\hline 2 & Hak berkeluarga dan melanjutkan keturunan & 2 \\
\hline 3 & Hak mengembangkan diri & 6 \\
\hline 4 & Hak memperoleh keadilan & 141 \\
\hline 5 & Hak atas kebebasan pribadi & 8 \\
\hline 6 & Hak atas rasa aman & 34 \\
\hline 7 & Hak atas kesejahteraan & 175 \\
\hline 8 & Hak turut serta dalam pemerintahan & 4 \\
\hline 9 & Hak wanita & 1 \\
\hline 10 & Hak anak & 4 \\
\hline 11 & Hak tidak diperlakukan diskriminatif & 1 \\
\hline \multicolumn{2}{|l}{ Total } & $\mathbf{3 9 3}$ \\
\hline
\end{tabular}

Dibalik eksistensi Komnas HAM dalam melakukan kajian dan penyelidikan HAM, masih terdapat beberapa kasus yang belum ditangani dengan tuntas dan kasus tersebut merupakan pelanggaran HAM berat, diantaranya: ${ }^{21}$

1) Peristiwa Tragedi $1965-1966$;

2) Peristiwa Penembakan Misterius 1982-1985;

3) Peristiwa Talang Sari di Lampung $1989^{22}$;

4) Peristiwa Penghilangan Orang Secara Paksa Periode 1997-1998;

5) Peristiwa Kerusuhan Mei 1998;

6) Peristiwa Trisakti, Semanggi I dan Semanggi II; dan

7) Peristiwa Wasior dan Wamena 2003.

\section{b. Komisi Perlindungan Anak Indonesia (KPAI)}

Ruang lingkup HAM yang begitu luas menjadi dasar bagi munculnya berbagai instrument yang memberikan perlindungan bagi segala aspek salah

\footnotetext{
19 www.komnasham.go.id diakses pada 3 april 2015, pkl.13:20, laporan bulanan sub bagian pengaduan Komnas HAM RI.

${ }^{20}$ berdasarkan UU No 39 tahun 1999 tentang Hak Asasi Manusia dan UU No 40 tahun 2008 tentang Penghapusan Diskriminasi Ras dan Etnis, dari 393 surat yang masuk tersebut dapat dikategorisasi lebih lanjut atas dasar 11 tema HAM.

${ }^{21}$ Wacana HAM, Lagi, Hasil Penyelidikan Dikembalikan, Edisi I/Tahun XII/2014, hlm. 11.

22 Peristiwa Talangsari 1989 adalah insiden yang terjadi di antara sebuah kelompok dengan aparat keamanan di Dusun Talangsari III, Desa Rajabasa Lama, Kecamatan Way Jepara, Kabutapen Lampung Timur (sebelumnya masuk Kabupaten Lampung Tengah). Peristiwa ini terjadi pada 7 Februari 1989.
} 
satunya mengenai perlindungan anak. Demikian dengan Indonesia yang juga memberikan porsi dalam melakukan perlindungan anak, dengan Konvensi Hak Anak yang telah diratifikasi dengan Keputusan Presiden Nomor 36 Tahun 1990 tentang Pengesahan Convention on The Rights of The Child (Konvensi tentang Hak Anak) ${ }^{23}$.

Pengaturan mengenai perlindungan anak juga diatur dalam ketentuan UU HAM ${ }^{24}$, dan secara spesifik diatur dalam UU No. 23 Tahun 2002 tentang Perlindungan Anak. Dalam ketentuan undang-undang tersebut mengamanatkan dibentuknya Komisi Perlindungan Anak (KPAI) yang bersifat independen ${ }^{25}$. Pantauan yang dilakukan oleh KPAI pada tahun 20072009 menunjukkan bahwa kekerasan yang dialami oleh anak masih tinggi, diantaranya ${ }^{26}$ :

\begin{tabular}{|c|l|c|c|c|}
\hline \multirow{2}{*}{ No } & \multicolumn{2}{|c|}{ Deskripsi } & \multicolumn{3}{c|}{ Jumlah } \\
\cline { 2 - 5 } & Bentuk Kekerasan & $\mathbf{2 0 0 9}$ & $\mathbf{2 0 0 8}$ & $\mathbf{2 0 0 7}$ \\
\hline 1 & Fisik & 605 & 436 & 341 \\
\hline 2 & Seksual & 705 & 626 & 527 \\
\hline 3 & Psikis & 688 & 764 & 624 \\
\hline 4 & Aborsi & - & 2567 & 4382 \\
\hline \multicolumn{2}{|r|}{ Jumlah } & $\mathbf{1 9 9 8}$ & $\mathbf{4 3 9 3}$ & $\mathbf{5 8 9 2}$ \\
\hline
\end{tabular}

Dengan begitu banyaknya kekerasan dan potensi kekerasan yang mungkin timbul terhadap anak, sehingga peran ${ }^{27}$ yang diamanatkan pada KPAI dalam perlindungan anak sangat dibutuhkan.

\section{c. Komnas Perempuan}

Salah satu dimensi HAM selain mengenai hak anak yaitu Komnas Perempuan, isu mengenai hak-hak perempuan bukanlah hal yang baru ${ }^{28}$.

${ }^{23}$ Disahkan dan diundangkan pada 25 Agustus 1990.

${ }^{24}$ Lihat Pasal 52-66 UU No. 39 Tahun 1999 tentang HAM.

25 Lihat Pasal 74 UU No. 23 Tahun 2002 tentang Perlindungan Anak.

${ }^{26}$ www.kpai.go.id, Kompilasi Pelanggaran Hak Anak 2007-2009, diakses pada 12 Desember 2015, pkl 16:16.

27 Melakukan sosialisasi seluruh ketentuan peraturan perundang-undangan yang berkaitan dengan perlindungan anak, mengumpulkan data dan informasi, menerima pengaduan masyarakat, melakukan penelaahan, pemantauan, evaluasi, dan pengawasan terhadap penyelenggaraan perlindungan anak; dan memberikan laporan, saran, masukan, dan pertimbangan kepada Presiden dalam rangka perlindungan anak.

${ }^{28}$ Istilah yang digunakan adalah man's right atau hak laki-laki. Hanya laki-laki yang diakui sebagai subjek hak, sementara perempuan tidak atau hanya dianggap sebagai nomor dua. Misalnya Konstitusi AS versi 1776, hak yang dimaksud adalah hak laki-laki. Lihat Jurnal Mahkamah Konstitusi Volume 11, Nomor 3, September 2014. 
Meskipun saat ini mengenai HAM telah memandang kesetaraan antara lakilaki dan wanita, namun muncul adanya Hak Wanita dalam UU No. 39 Tahun 1999 tentang HAM yang merupakan bagian dari HAM $^{29}$.

Hal ini didasari banyaknya ketidaksetaraan dan kekerasan yang dialami oleh wanita, sehingga Komite PBB untuk Penghapusan Diskriminasi Terhadap Perempuan (CEDAW) ${ }^{30}$ pada sidangnya yang ke 11 tahun 1992 mengeluarkan Rekomendasi Umum No. 19 tentang Kekerasan Terhadap Perempuan. Dalam rekomendasi ini dinyatakan bahwa "kekerasan berbasis gender adalah suatu bentuk diskriminasi yang secara serius menghalangi kesempatan wanita untuk menikmati hak-hak dan kebebasannya atas suatu dasar kesamaan hak dengan laki-laki" (LBH APIK, tanpa tahun). Indonesia telah meratifikasi Konvensi Penghapusan Segala Bentuk Diskriminasi Terhadap Perempuan (Convention on the Elimination of All Form of Discrimination Against Women,1979) dengan UU No. 7 Tahun 1984 mengenai Pengesahan Konvensi Tentang Penghapusan Segala Bentuk Diskriminasi Terhadap Perempuan ${ }^{31}$. Dalam perkembangannya disusul dengan PBB mengeluarkan Deklarasi tentang Penghapusan Kekerasan Terhadap Perempuan (The Declaration on the Elimination of Violence Against Women) $)^{32}$.

${ }^{29}$ Lihat Pasal 45 UU No. 39 Tahun 1999 tentang HAM.

${ }^{30}$ Definisi tentang diskriminasi terhadap perempuan dimuat dalam Pasal 1 CEDAW yaitu: "...shall mean any distinction, exclusion or restriction made on the basis of sex which has the effect or purpose of impairing or nullifying the recognition, enjoyment or exercise by women, irrespective of their maritalstatus, on a basis of equality of men and women, of human rights and fundamental freedoms in the political, economic, social, cultural, civil or any other field".

${ }^{31}$ Kajian Dampak Kekerasan Terhadap Status Kesehatan Perempuan di Provinsi DKI Jakarta dan Provinsi di Yogyakarta 2005, oleh Komisi Nasional Anti Kekerasan Terhadap Perempuan, hlm. 6-7.

${ }^{32}$ Pasal 1 Deklarasi menyatakan : Kekerasan terhadap perempuan adalah setiap perbuatan berdasarkan perbedaan jenis kelamin yang berakibat atau mungkin berakibat pada kesengsaraan atau penderitaan perempuan secara fisik, seksual, atau psikologis, termasuk ancaman perbuatan tertentu, pemaksaan atau perampasan kemerdekaan secara sewenangwenang baik yang terjadi di depan umum maupun dalam kehidupan pribadi, dan Pasal 2 Deklarasi menyatakan : "kekerasan terhadap perempuan harus dipahami mencakup, tetapi tidak hanya terbatas pada: tindak kekerasan secara fisik, seksual dan psikologis yang terjadi di dalam keluarga dan di masyarakat, termasuk pemukulan, penyalahgunaan seksual atas perempuan kanak-kanak, kekerasan yang berhubungan dengan mas kawin, perkosaan dalam perkawinan (marital rape), perusakan alat kelamin perempuan dan praktik-praktik kekejaman tradisional lain terhadap perempuan, kekerasan yang berhubungan dengan eksploitasi perempuan, perkosaan, penyalahgunaan seksual, pelecehan dan ancaman seksual di tempat kerja, lembaga-lembaga pendidikan dan sebagainya, perdagangan perempuan dan pelacuran paksa. Serta termasuk kekerasan yang dilakukan dan dibenarkan oleh negara di manapun terjadinya. 


\section{d. Komisi Kebenaran dan Rekonsiliasi}

Setelah berakhirnya masa orde baru, babak baru dimulai Negara Indonesia dengan beberapa permasalahan yang masih tersisa, salah satu adalah menyelesaikan pelanggaran HAM yang dilakukan oleh penguasa orde baru. Dorongan untuk menyelesaikan persoalan HAM telah dimulai sejak pemerintahan B.J. Habibie, K.H. Abdurrahman Wahid hingga ke pemerintahan Megawati. Dorongan agar kasus pelanggaran HAM segera dituntaskan semakin kuat saat Komnas HAM terbentuk.

Salah satu mekanisme yang digunakan untuk menyelesaikan persoalan pelanggaran HAM berat yang terjadi di Indonesia diantaranya membentuk Komisi Kebenaran dan Rekonsiliasi (KKR). Munculnya KKR sebagai bentuk implementasi Ketetapan MPR No.V/MPR/2000 tentang Pemantapan Persatuan dan Kesatuan Nasional ${ }^{33}$ dan UU Nomor 26 Tahun 2000 tentang Pengadilan $\mathrm{HAM}^{34}$. Mencermati dua ketentuan pokok dalam pembentukan Komisi Kebenaran dan Rekonsiliasi maka terdapat hal-hal yang substansial diatur, diantaranya: (1) dalam UU No. 26 Tahun 2000 tentang Pengadilan HAM mengatur adanya upaya penyelesaian oleh Komisi Kebenaran dan Rekonsiliasi ${ }^{35}$ disamping penegakan hukum oleh Pengadilan HAM. Selain itu upaya yang ditempuh oleh melalui adanya Komisi Kebenaran dan Rekonsiliasi dengan maksud agar menyelesaikan pelanggaran hak asasi manusia yang berat yang terjadi pada masa lalu di luar pengadilan, guna mewujudkan perdamaian dan persatuan bangsa; dan mewujudkan rekonsiliasi dan persatuan nasional dalam jiwa saling pengertian ${ }^{36}$.

\footnotetext{
${ }^{33}$ Lihat pada Bab I huruf B Alinea kedua menegaskan bahwa: Kesadaran dan komitmen yang sungguh-sungguh untuk memantapkan persatuan dan kesatuan nasional harus diwujudkan dalam langkah-langkah nyata berupa pembentukan Komisi Kebenaran dan Rekonsiliasi Nasional serta merumuskan etika berbangsa dan visi Indonesia masa depan, dan Bab V angka 3 yang menegaskan bahwa: Komisi ini bertugas untuk menegakkan kebenaran dengan mengungkapkan penyalahgunaan kekuasaan dan pelanggaran HAM di masa lampau sesuai dengan hukum dan peraturan perundang-undangan yang berlaku, dan melaksanakan rekonsiliasi dalam perspektif kepentingan bersama sebagai bangsa.

${ }^{34}$ Lihat Umum Penjelasan UU No. 26 Tahun 2000 tentang Pengadilan HAM, yaitu: Di samping adanya Pengadilan HAM ad hoc, Undang-undang ini menyebutkan juga keberadaan Komisi Kebenaran dan Rekonsiliasi sebagaimana dimaksud dalam Ketetapan MPR-RI Nomor V/MPR/2000 tentang Pemantapan Persatuan dan Kesatuan Nasional. Komisi Kebenaran dan Rekonsiliasi yang akan dibentuk dengan undang-undang dimaksudkan sebagai lembaga extra-judicial yang ditetapkan dengan undang-undang yang bertugas untuk menegakkan kebenaran dengan mengungkapkan penyalahgunaan kekuasaan dan pelanggaran hak asasi manusia pada masa lampau, sesuai dengan ketentuan hukum dan perundang-undangan yang berlaku dan melaksanakan rekonsiliasi dalam perspektif kepentingan bersama sebagai bangsa.

${ }^{35}$ Lihat Pasal 47 ayat (1) dan (2) UU N. 26 Tahun 2000 tentang Pengadilan HAM.

${ }^{36}$ Lihat Pasal 3 huruf a dan b UU No. 27 Tahun 2004 tentang Komisi Kebenaran dan Rekonsiliasi.
} 
Dasar hukum tentang pembentukan KKR diatur dalam UndangUndang Nomor 27 Tahun 2004 tentang Komisi Kebenaran dan Rekonsiliasi. Secara garis besar, Ketua Panitia Khusus RUU KKR Sidharto Danusubroto mengidentifikasi titik krusial perjalanan panjang RUU KKR menjadi UU KKR yang dapat dikelompokkan berikut: a) saat RUU KKR ini diserahkan oleh pemerintah kepada DPR untuk dibahas yang kemudian ditindaklanjuti dengan membentuk suatu pansus. Beragama persoalan muncul terkait dengan konteks pelaku-korban adalah ketidakjelasan pelaku dan status hukum korban yang masih terdiskriminasi dan pemaknaan terhadap institusi KKR.; b) Terkait hak korban atas kompensasi, restitusi dan rehabilitasi. Banyak pihak melihat bahwa hak korban telah digadaikan dengan adanya ketentuan pemberian amnesti.; c) Terkait kelanjutan kasus-kasus pelanggaran HAM itu sendiri, misalnya apakah sebuah kasus yang telah ditangani oleh KKR, namun ternyata tidak terjadi rekonsiliasi masih memunyai harapan untuk diselesaikan atau apabila amnesti yang diajukan pelaku tidak dipenuhi sehingga tidak terjadi rekonsiliasi masih bisa diadili melalui Pengadilan HAM Ad hoc.; d) Terkait saratnya kepentingan politik yang terlibat dalam pembahasan RUU KKR yang membawa implikasi pada panjangnya waktu dan besarnya energi yang dikeluarkan, sedangkan sarana pendukungnya tidak disediakan secara optimal ${ }^{37}$. Pada akhirnya dibentuklah sebuah Komisi Kebenaran dan Rekonsiliasi namun hingga saat ini kita belum memiliki landasan hukum yang berkaitan dengan mekanisme kerja ${ }^{38}$. Komisi Kebenaran dan Rekonsiliasi ini bertugas untuk: ${ }^{39}$

1) menerima pengaduan atau laporan dari pelaku, korban, atau keluarga korban yang merupakan ahli warisnya;

2) melakukan penyelidikan dan klarifikasi atas pelanggaran HAM berat;

3) memberikan rekomendasi kepada presiden dalam hal permohonan amnesti;

4) menyampaikan rekomendasi kepada pemerintah dalam hal pemberian kompensasi dan/atau rehabilitasi; dan

${ }^{37}$ Endang Sri Melani, Perlindungan Hak-Hak Korban Pelanggaran Hak Asasi Manusia Berat Di Timor Timur Dalam Putusan Pengadilan Ham Nomor: 02/PID.HAM/AD.HOC/2002/PN.JKT.PST, Tesis, Program Pascasarjana Fakultas Hukum Universitas Indonesia, 127-128.

38 Satya Arinanto, Komisi Kebenaran dan Rekonsiliasi: Permasalahan dan Prospek Pembentukannya di Indonesia, Makalah Disampaikan Pada: Seminar Pembangunan Hukum Nasional VIII Tema Penegakan Hukum Dalam Era Pembangunan Berkelanjutan Diselenggarakan Oleh Badan Pembinaan Hukum Nasional Departemen Kehakiman Dan Hak Asasi Manusia RI Denpasar, 14 - 18 Juli 2003.

${ }^{39}$ Lihat Pasal 6 Undang-Undang Nomor 27 Tahun 2004 tentang Komisi Kebenaran dan Rekonsiliasi. 
5) menyampaikan laporan tahunan dan laporan akhir tentang pelaksanaan tugas dan wewenang berkaitan dengan perkara yang ditanganinya, kepada presiden dan DPR dengan tembusan kepada Mahkamah Agung.

Dalam perjalannya kemudian, UU KKR ini diajukan judicial review di Mahkamah Konstitusi, berkaitan dengan Pasal 1 ayat (9), Pasal 27 dan Pasal 44. Dalam Putusan Mahkamah Konstitusi Nomor 006/PUU-IV/2006 menyatakan bahwa pasal-pasal yang dimohonkan oleh pemohon tidak memiliki kekuatan hukum tetap ${ }^{40}$.

\section{Lembaga Peradilan sebagai Penegakan HAM a. Pengadilan HAM}

Perkembangan dan terobosan yang sangat baik lahir dalam masa reformasi adalah dengan munculnya mekanisme penyelesaian kasus pelanggaran hak asasi manusia melalui Pengadilan Hak Asasi Manusia (Pengadilan HAM). Pengadilan HAM merupakan salah satu instrumen yang penting dalam penegakan dan perlindungan HAM. Pengadilan HAM diatur secara khusus dalam Undang-Undang Nomor 26 Tahun 2000 tentang Pengadilan $\mathrm{HAM}^{41}$ yang menganut asas retroaktif.

Dengan ketentuan asas retroaktif demikian dapat mengadili pelanggaran HAM yang terjadi sebelum undang-undang ini diberlakukan ${ }^{42}$

${ }^{40}$ Lihat dalam Putusan Mahkamah Konstitusi Nomor 006/PUU-IV/2006, MK menilai bahwa muatan dalam UU No. 27 ahun 2004 tentang Komisi Kebenaran dan Rekonsiliasi justru tidak memunyai kekuatan hukum mengikat, sehingga muatan dalam undang-undang tersebut dibatalkan seluruhnya. "...Mahkamah berpendapat bahwa asas dan tujuan KKR, sebagaimana termaktub dalam Pasal 2 dan Pasal 3 undang-undang a quo, tidak mungkin dapat diwujudkan karena tidak adanya jaminan kepastian hukum (rechtsonzekerheid). Oleh karena itu, Mahkamah menilai undang-undang a quo secara keseluruhan bertentangan dengan UUD 1945 sehingga harus dinyatakan tidak memunyai kekuatan hukum mengikat..."

${ }^{41}$ Lembaran Negara Republik Indonesia Tahun 2000 Nomor 208.

${ }^{42}$ Lihat penjelasan umum dalam UU Nomor 26 Tahun 2000 tentang Pengadilan HAM: "Mengenai pelanggaran hak asasi manusia yang berat seperti genosida dan kejahatan terhadap kemanusiaan yang berdasarkan hukum internasional dapat digunakan asas retroaktif, diberlakukan pasal mengenai kewajiban untuk tunduk kepada pembatasan yang ditetapkan dengan undang-undang sebagaimana tercantum dalam Pasal 28 J ayat (2) Undang-Undang Dasar 1945 yang berbunyi: "Dalam menjalankan hak dan kebebasannya setiap orang wajib tunduk kepada pembatasan yang ditetapkan dengan undang-undang dengan maksud semata-mata untuk menjamin pengakuan serta penghormatan atas hak dan kebebasan orang lain dan untuk memenuhi tuntutan yang adil sesuai dengan pertimbangan moral, nilai-nilai agama, keamanan, dan ketertiban umum dalam suatu masyarakat demokratis". Dengan ungkapan lain asas retroaktif dapat diberlakukan dalam rangka melindungi hak asasi manusia itu sendiri berdasarkan Pasal $28 \mathrm{~J}$ ayat (2) Undang-Undang Dasar 1945 tersebut. Oleh karena itu Undang-undang ini mengatur pula tentang Pengadilan HAM ad hoc untuk memeriksa dan memutus perkara pelanggaran hak asasi manusia yang berat yang terjadi sebelum diundangkannya Undang-undang ini. Pengadilan HAM ad hoc 
melalui Pengadilan HAM Ad $\mathrm{Hoc}^{43}$. Dengan ketentuan asas tersebut sesungguhnya bertentangan dengan asas legalitas ${ }^{44}$ yang dianut oleh Negara Indonesia, namun dengan baik ditinjau dari kepentingan nasional maupun dari kepentingan internasional, maka untuk menyelesaikan masalah Pelanggaran HAM Berat dan mengembalikan keamanan dan perdamaian di Indonesia serta perlindungan hak atas keadilan diperlukan pembentukan Pengadilan HAM yang merupakan pengadilan khusus bagi pelanggaran hak asasi manusia yang berat.

Pembentukan Pengadilan HAM pertama kali diterbitkan pada masa pemerintahan Presiden Abdurrahman Wahid melalui Keputusan Presiden (Keppres) Nomor 53 Tahun 2001 tentang Pembentukan Pengadilan HAM Ad hoc pada Pengadilan Negeri Jakarta Pusat pada 23 April 200145. Namun, belum sempat Keppres itu dilaksanakan, pada awal Pemerintahan Presiden Megawati, Keppres tersebut mengalami perubahan dengan terbitnya Keppres Nomor 96 Tahun 2001 tentang Perubahan atas Keputusan Presiden Nomor 53 Tahun 2001 tentang pembentukan Pengadilan HAM Ad Hoc pada Pengadilan Negeri Jakarta Pusat. Keberadaan Pengadilan HAM merupakan terobosan yang signifikan bagi penegakan HAM itu sendiri, diamanatkan dalam UU Nomor 26 Tahun 2000 bahwa dapat menjangkau pelanggar HAM di luar batas teritorial Negara Indonesia ${ }^{46}$ yang melakukan pelanggaran HAM berat ${ }^{47}$. Beberapa kasus yang menjadi fokus tuntutan pelanggaran HAM berat agar diselesaikan oleh Pengadilan HAM diantaranya: kasus Trisakti (12 Mei 1998), Semanggi I (13 November 1998), dan Semanggi II (22-24 September 1998). Ada pula kasus-kasus lainnya yang juga dituntut untuk diselesaikan seperti kasus pelanggaran HAM berat di Tanjung Priok (12 September 1984), kasus pelanggaran HAM berat di Aceh semasa penerapan kebijakan Daerah Operasi Militer (DOM) pada tahun 1989-1999,

dibentuk atas usul Dewan Perwakilan Rakyat berdasarkan peristiwa tertentu dengan Keputusan Presiden dan berada di lingkungan Peradilan Umum.

${ }^{43}$ Lihat Pasal 43 UU No. 26 Tahun 2000, yaitu :

1.Pelanggaran HAM Berat yang terjadi sebelum diundangkannya undang-undang ini, diperiksa dan diputus oleh Pengadilan HAM ad hoc;

2.Pengadilan HAM ad hoc sebagaimana dimaksud dalam ayat (1) dibentuk atas usul DPR RI berdasarkan peristiwa tertentu dengan Keputusan Presiden;

3.Pengadilan HAM ad hoc sebagaimana dimaksud dalam ayat (1) berada di lingkungan Peradilan Umum.

${ }^{44}$ Lihat Pasal 1 KUHP: "suatu perbuatan tidak dapat dipidana, kecuali berdasarkan kekuatan ketentuan perundang-undangan pidana yang telah ada".

${ }^{45}$ Pembentukan Keppres ini dilakukan sebagai pelaksanaan dari Pasal 43 ayat (1) UU Nomor 26 Tahun 2000 tentang Pengadilan HAM yang menentukan bahwa Pelanggaran HAM Berat yang terjadi sebelum berlakunya undang-undang tersebut diperiksa dan diputus oleh Pengadilan HAM Ad hoc.

${ }^{46}$ Lihat Pasal 5 UU Nomor 26 Tahun 2000 tentang Pengadilan HAM.

${ }^{47}$ Lihat Pasal 4 UU Nomor 26 Tahun 2000 tentang Pengadilan HAM. 
dan kasus pelanggaran HAM berat di Timor-Timur dalam wilayah hukum Liquica, Dili, dan Suai ${ }^{48}$ selain itu Komnas HAM menjadikan 3 (tiga) kasus yang telah diselidiki diajukan ke pengadilan HAM. Dua pengadilan HAM ad hoc untuk kasus Timor-timur dan Tanjung Priok, dan satu Pengadilan HAM di Makassar untuk kasus Abepura (selanjutnya semua disebut dengan Pengadilan HAM).

Salah satu kasus yang kemudian tidak terselesaikan dengan tuntas dalam pengadilan HAM adalah kasus Trisakti, Semanggi I dan Semanggi II. Kasus yang melibatkan mahasiswa dan mengakibatkan 4 mahasiswa Trisakti meninggal dunia tersebut telah sampai pada pembentukan Panitia Khusus (Pansus) $^{49}$. Dari pandangan terhadap kasus di atas, terbagi menjadi dua golongan, diantaranya: (1) Kelompok yang merekomendasikan diselesaikan dalam Pengadilan Umum atau Pengadilan Militer ${ }^{50}$; (2) Kelompok yang merekomendasikan diselesaikan dalam Pengadilan HAM Ad Hoc ${ }^{5 I}$.

Dalam Rapat Pleno Pansus diadakanlah voting terhadap penyelesaian kasus tersebut, dengan hasil 14 suara setuju untuk merekomendasikan agar kasus-kasus tersebut diselesaikan melalui Pengadilan Umum atau Pengadilan Militer dan 5 suara setuju dengan rekomendasi agar Presiden mengeluarkan Keppres tentang pembentukan Pengadilan HAM Ad Hoc dari 19 anggota Pansus yang hadir, dan dari total 26 orang anggota pansus ${ }^{52}$. Dengan demikian maka penyelesaian dilakukan dengan Pengadilan Umum atau Pengadilan Militer, putusan yang demikian mengindikasikan adanya keengganan diselesaikan dalam Pengadilan HAM Ad Hoc. Hal ini dilihat dari tingkatan penjatuhan hukuman dalam Pengadilan HAM yang tergolong berat $^{53}$. Kasus ini akan berkaitan dengan salah satu prinsip yang ditawarkan

${ }^{48}$ Satya Arinanto, Hak Asasi Manusia dalam., Op.cit., hlm. 279.

${ }^{49}$ DPR menerbitkan Surat Keputusan (SK) Dewan Perwakilan Rakyat Republik Indonesia Nomor 29/DPR-RI/III/2000-2001 tanggal 15 januari 2000 tentang Pembentukan Panitia Khusus Dewan Perwakilan Rakyat Republik Indonesia mengenai Kasus Trisakti, Kasus Semanggi I, dan Kasus Semanggi II".

${ }^{50}$ Fraksi yang mendukung diantaranya Fraksi Partai Golkar (F-PG), Fraksi Partai Persatuan Pembangunan (F-PPP), Fraksi Reformasi, Fraksi Tentara Nasional Indonesia/Kepolisian Republik Indonesia (F-TNI/POLRI), dan Fraksi Persatuan Daulat Ummah (F-PDU).

${ }^{51}$ Fraksi yang mendukung diantaranya Fraksi Partai Demokrasi Indonesia-Perjuangan (FPDIP), Fraksi Partai Kebangkitan Bangsa (F-PKB), dan Fraksi Demokrasi Kasih Bangsa (FPDKB).

${ }^{52}$ Satya Arinanto, Hak Asasi Manusia dalam., Op.cit., hlm. 329.

${ }^{53}$ Lihat Pasal 36 Setiap orang yang melakukan perbuatan sebagaimana dimaksud dalam Pasal 8 huruf a, b, c, d, atau e dipidana dengan pidana mati atau pidana penjara seumur hidup atau pidana penjara paling lama 25 (dua puluh lima) tahun dan paling singkat 10 (sepuluh) tahun.; Pasal 37 Setiap orang yang melakukan perbuatan sebagaimana dimaksud dalam Pasal 9 huruf a, b, d, e, atau j dipidana dengan pidana mati atau pidana penjara seumur hidup atau pidana penjara paling lama 25 (dua puluh lima) tahun dan paling singkat 10 (sepuluh) tahun.; Pasal 38 Setiap orang yang melakukan perbuatan sebagaimana dimaksud dalam Pasal 9 huruf c, dipidana dengan pidana penjara paling lama 15 (lima belas) tahun 
oleh hukum internasional Hak Asasi Manusia (HAM) yakni prinsip akuntabilitas (accountability principle). Prinsip akuntabilitas jika diterapkan pada peradilan HAM memunyai makna lembaga pengadilan ini diminta mengadili secara fair dan imparsial para pelaku kejahatan HAM berat untuk mempertanggungjawabkan kejahatan yang telah dilakukannya ${ }^{54}$.

\section{b. Mahkamah Konstitusi}

Secara teoretis keberadaan Mahkamah Konstitusi diperkenalkan oleh Hans Kelsen, yang menyatakan bahwa pelaksanaan aturan konstitusional tentang legislasi dapat secara efektif dijamin hanya jika suatu organ selain badan legislatif diberikan tugas untuk menguji apakah suatu produk hukum itu konstitusional atau tidak, dan tidak memberlakukannya jika menurut organ ini produk hukum tersebut tidak konstitusional ${ }^{55}$. Namun, selain menguji suatu produk hukum, Mahkamah Konstitusi juga sebagai penjaga konstitusi yang muatannya mengenai hak asasi warga negara.

Ide pembentukan Mahkamah Konstitusi bukanlah hal baru, hal ini dapat dilihat dalam perdebatan Mr. Soepomo dan Muhammad Yamin dalam sidang-sidang BPUPKI. Muhammad Yamin adalah yang pertama kali mengusulkan agar kepada Mahkamah Agung, yang awalnya disebut Balai Agung, diberi kewenangan untuk "membanding undang-undang", demikian istilah yang dipakai olehnya ketika itu. Kegiatan membanding undangundang itu, menurut Yamin, dapat dilakukan dengan cara membandingkan setiap produk undang-undang dengan tiga sistem norma, yaitu: (i) undangundang dasar (ii) hukum syari' at Islam (iii) hukum adat ${ }^{56}$. Sampai pada saat sebelum terjadinya amandemen UUD 1945, fungsi pengujian diberikan kewenangannya pada Mahkamah Agung. Pada saat pembahasan perubahan UUD 1945 dalam era reformasi, yang menghendaki hilangnya supremasi pada satu lembaga. Akhirnya menyebabkan MPR tidak lagi berkedudukan sebagai lembaga tertinggi Negara dan supremasi telah beralih dari supremasi MPR kepada supremasi Konstitusi ${ }^{57}$.

Jika ditarik ke masa lebih awal, konsepsi ini lahir sebagai buah perkembangan pemikiran dari gagasan tentang negara hukum, prinsip

dan paling singkat 5 (lima) tahun. Dalam UU Nomor 26 Tahun 2000 tentang Pengadilan HAM.

${ }^{54}$ A.Patra M. Zen, Tak Ada hak Asasi yang Diberi, (Jakarta: Yayasan YLBHI, 2005), hlm. 75.

55 Jimly Asshiddiqie, Menuju Negara Hukum yang Demokratis, (Jakarta: PT Bhuana Ilmu Populer, 2009), hlm. 333.

56 Jimly Asshiddiqie, Pokok-Pokok Hukum Tata Negara Indonesia Pasca Reformasi, (Jakarta: PT Bhuana Ilmu Populer, 2007), hlm. 581.

${ }^{57}$ Lihat Pasal 1 Ayat (2) Undang - Undang Dasar Negara Republik Indonesia 1945, lihat juga H. Endang Komara, Peranan Mahkamah Konstitusi dalam Mewujudkan Masyarakat Madani di Indonesia, Jurnal Konstitusi Mahkamah Konstitusi RI Volume 4 Nomor 4, hlm.78, 2007. 
pemisahan kekuasaan, dan upaya perlindungan serta pemajuan hak asasi manusia. Dengan demikian, konsep "constitutional review" merupakan kolaborasi tiga ide dasar tersebut, sebagai jawaban atas kebutuhan adanya suatu pemerintahan modern yang demokratis ${ }^{58}$. Dapat dikatakan bahwa konsentrasi pada kekuasaan secara berlebihan tanpa kontrol menimbulkan kesewenangan, sebagaimana dikemukakan oleh Lord Acton "Power tends to corrupt, and absolute power corrupts absolutely" ${ }^{\text {. }}$. Setelah disahkannya Perubahan Ketiga UUD 1945 maka dalam rangka pelaksanaan kemudian dibentuklah Mahkamah Konstitusi sebagai lembaga baru yang dibentuk pasca amandemen ke 3 UUD 1945, dengan perubahan pada Bab IX tentang Kekuasaan Kehakiman Pasal 24 khususnya Pasal 24C dan dibentuknya UU No. 24 Tahun 2003 tentang Mahkamah Konstitusi, sebagai bentuk menjaga kesakralan konstitusi.

Jika dilihat dari perspektif peraturan perundang-undang yang dibuat baik oleh primary legislator, dalam hal ini DPR dan pemerintah (berupa undang-undang), maupun secondary legislator tidak selalu peka terhadap HAM. Terkadang kebijakan dikeluarkan secara sewenang-wenang, sehingga berpotensi untuk terjadinya pelanggar hak asasi manusia. Ketentuan dalam UUD 1945 memberikan ruang bagi setiap warga negara yang merasa haknya dilanggar untuk menggujinya melalui mekanisme judicial review kepada Mahkamah Agung dan Mahkamah Konstitusi ${ }^{60}$. Konsep judicial review berasal dari negara-negara yang menganut prinsip supremasi konstitusi. Menurut Soepomo, di Belanda tidak dikenal istilah judicial review ${ }^{61}$, mereka hanya mengenal istilah hak menguji (toetsingensrecht). Judicial review merupakan mekanisme pengujian peraturan perundang-undangan tertentu oleh hakim. Pengujian itu dilakukan atas suatu ketentuan peraturan perundang-undangan terhadap peraturan perundang-undangan yang lebih tinggi atau terhadap konstitusi sebagai hukum tertinggi ${ }^{62}$. Dengan

58 Ja'far Baehaqi, Perspektif Penegakan Hukum Progresif dalam Judicial Review di Mahkamah Konstitusi, Jurnal Mahkamah Konstitusi, Volume 10 Nomor 3, September 2013, hlm. 424.

59 Jimly Asshiddiqie, Konstitusi dan Konstitualisme Indonesia, (Jakarta: Konstitusi Press, Jakarta, 2005), hlm. 156.

60 Saldi Isra, Peran Mahkamah Konstitusi dalam Penguatan Hak Asasi Manusia Di Indonesia, Jurnal Mahkamah Konstitusi Volume 11, Nomor 3, September 2014, hlm. 419420.

${ }^{61}$ Istilah judicial review itu sendiri merupakan istilah khas hukum tata negara Amerika Serikat yang artinya wewenang lembaga pengadilan untuk membatalkan setiap tindakan pemerintahan yang bertentangan dengan konstitusi. Lihat Fatmawati, Hak Menguji (Toetsingrecht) yang dimiliki hakim dalam sistem hukum indonesia, (Jakarta: Raja Grafindo, 2005), hlm. 5.

${ }^{62}$ Moh Mahfud MD, Makalah disampaikan dalam Acara Orientasi Anggota DPR RI Fraksi PDI Perjuangan 2009-2014 pada Selasa, 8 September 2009 di Ball Room Hotel Harris Tebet, Jakarta. Dengan Judul Konstitusi Negara. 
kewenangan yang dimiliki, maka Mahkamah Konstitusi memiliki peran dalam menegakan HAM di Indonesia. Sebagaimana dalam Pasal 24C Ayat (1) dan (2) UUD 1945 dan Pasal 10 Ayat (1) UU No. 24 Tahun 2003 tentang Mahkamah Konstitusi, bahwa dengan kewenangan sebagai The Guardian of the Constitution, MK menurut, Jimly Asshiddiqie, menguraikan mengenai Mahkamah Konstitusi sebagai berikut:

"Dalam konteks ketatanegaraan, Mahkamah Konstitusi dikonstruksikan sebagai pengawal konstitusi yang berfungsi menegakkan keadilan konstitusional di tengah kehidupan masyarakat. Mahkamah Konstitusi bertugas mendorong dan menjamin agar konstitusi dihormati dan dilaksanakan oleh semua komponen negara secara konsisten dan bertanggung jawab. Di tengah kelemahan sistem konstitusi yang ada, Mahkamah Konstitusi berperan sebagai penafsir agar spirit konstitusi selalu hidup dan mewarnai keberlangsungan bernegara dan bermasyarakat." ${ }^{63}$

Sehingga tujuan konstitusi sebagai hukum tertinggi, yang memuat: 1 . Keadilan (justice); 2. Ketertiban (order); 3. Perwujudan nilai-nilai kebebasan (freedom) dan kemakmuran dan kesejahteraan (prosperity and walfare) ${ }^{64}$, dan kehadiran Mahkamah Konstitusi dapat mengarahkan, mendorong dan menjamin agar konstitusi dilaksanakan secara konsisten dalam konteks menegakan konstitusi sebagai hukum tertinggi dan melaksanakan hukum di Indonesia.

Secara ketatanegaraan kedudukan putusan Mahkamah Konstitusi yang disebut vonis adalah termasuk keputusan negara yang mengandung norma hukum, sama halnya dengan putusan pembentuk undang-undang yang bersifat pengaturan (regelling) ${ }^{65}$. Selain putusan Putusan Nomor 31/PUUV/2007 yang memberikan ketentuan mengenai kesatuan hukum masyarakat adat, masih terdapat putusan Mahkamah Konstitusi yang memberikan dampak konstitusional pada eksistensi HAM, diantaranya: 1) Putusan MK No. 47-81/PHPU.A/VII/2009; 2) Putusan MK No 35/PUU-X/2012.; 3) Putusan MK No 31/PUU-V/2007; 4) Putusan MK No 011-017/PUU-I/2003; 5) Putusan MK No 6-13-20/PUU-VIII/2010; 6) Putusan MK No 27/PUUIX/2011.

\footnotetext{
${ }^{63}$ Maruarar Siahaan, Hukum Acara Mahkamah Konstitusi Republik Indonesia, (Jakarta: Sinar Grafika, 2011), hlm. 8.

${ }^{64}$ Jimly Asshiddiqie, Konstitusi Ekonomi, (Jakarta: PT Kompas Media Nusantara, 2010), hlm. 9.

${ }^{65}$ Taufiqurrohman Syahuri, Tafsir Konstitusi Berbagai Aspek Hukum, (Jakarta: Kencana Prenada Media Group, 2011), hlm. 119.
} 


\section{1) Pilkada dan HAM atas Hak Adat (Putusan Mahkamah Konstitusi Nomor 47-81/PHPU.A/VII/2009)}

Dalam perkara Nomor 47-81/PHPU.A/VII/2009. Mahkamah Konstitusi memberikan pengakuan hak politik kepada peserta pemilihan umum, diantaranya: a) Pengakuan penggunaan "Noken"66, dan b) Pengakuan pemilihan umum dengan sistem suara kolektif dalam sebuah pemilihan umum di Papua, yang terungkap dalam persidangan adalah sah dilakukan. Namun, Hakim Konstitusi Maria Farida menjelaskan bahwa pelaksanaan sistem noken bersifat kasuistis. MK memperbolehkan pelaksanaan sistem noken karena ada kasus konkret dalam perkara Pemilukada, bukan dalam perkara pengujian konstitusionalitas Undang-Undang. ${ }^{67}$ Putusan Mahkamah Konstitusi ini kemudian berdampak dalam ketentuan teknis yang diatur dalam keputusan yang kemudian ditetapkan oleh Komisi Pemilihan Umum Provinsi Papua (KPU Provinsi) ${ }^{68}$. MK juga merujuk pada Putusan Nomor 47-81/PHPU.A-VII/200969, menyatakan :

“... Mahkamah dapat memahami dan menghargai nilai budaya yang hidup di kalangan masyarakat Papua yang khas dalam menyelenggarakan pemilihan umum dengan cara atau sistem "kesepakatan warga" atau "aklamasi". Mahkamah menerima cara pemilihan kolektif ("kesepakatan warga" atau "aklamasi") yang telah diterima masyarakat Kabupaten Yahukimo tersebut, karena jika dipaksakan pemilihan umum sesuai dengan peraturan perundang-undangan yang berlaku dikhawatirkan akan timbul konflik di antara kelompok-kelompok masyarakat setempat".

Sehingga permohonan Pemohon tentang ketidaksetujuan mengenai pemilihan secara aklamasi harus dikesampingkan, karena sebagai bentuk penghormatan akan nilai-nilai adat dan berpotensi menimbulkan konflik. Disamping itu, penggunaan Noken telah disepakati bersama secara demokratis dan adil oleh masyarakat adat sendiri. Fakta ini mengikat

\footnotetext{
${ }^{66}$ Noken adalah sebutan untuk (kantong) tas khas buatan orang Papua. Tas ini merupakan hasil kerajinan tangan khas Papua yang dibuat dari kulit kayu. Noken biasanya tergantung di kepala atau leher perempuan Papua yang digunakan untuk membawa hasil bumi, babi, atau bahkan untuk menggendong bayi. Bagi orang Papua, Noken juga dimaknai sebagai simbol kehidupan yang baik, perdamaian dan kesuburan. Karena itu, kantong (tas) yang dijalin dari kulit kayu ini punya kedudukan penting dalam struktur budaya orang Papua. Dalam beberapa kali pemilu, baik pemilu presiden maupun pemilu legislatif, noken dipakai sebagai tempat untuk meletakkan kertas suara yang sudah dicoblos/dicontreng.

67 Siaran Pers Mahkamah Konstitusi, Warga Papua Uji Sistem Pemungutan Suara dalam Pemilu, Jakarta, 14 April 2014.

${ }^{68}$ Lihat Keputusan Komisi Pemilihan Umum Provinsi Papua Nomor: 01/Kpts/KPU Prov. 030/2013 tentang Petunjuk Teknis Tata Cara Pemungutan Suara dengan Menggunakan Noken Sebagai Pengganti Kotak Suara.

${ }^{69}$ Putusan MK pada tanggal 9 Juni 2009.
} 
berdasarkan yurisprudensi dan dijadikan dasar memutus sengketa Pemilukada Kabupaten Yahukimo, dan menjadi upaya pengakuan hak adat sebagai bagian dari hak asasi manusia dan bangunan hukum nasional ${ }^{70}$.

\section{2) Terpisahnya Hutan Adat dari Hutan Negara (Putusan Mahkamah Konstitusi Nomor 35/PUU-X/2012)}

Sedangkan dalam perkara Nomor 35/PUU-X/2012 ${ }^{71}$, Mahkamah Konstitusi memberikan keputusan yang sangat berdampak dalam pemetaan hutan negara dan hutan adat. Permohonan yang diajukan oleh Aliansi Masyarakat Adat Nusantara (AMAN), Kesatuan Masyarakat Hukum Adat Kenegerian Kuntu dan Kesatuan Masyarakat Adat Kasepuhan Cisitu. Pemohon menilai sejak berlakunya UU Kehutanan terbukti sebagai alat negara untuk mengambil alih hutan hak kesatuan masyarakat adat dalam mengelola hutan yang kemudian dijadikan hutan negara. Atas nama negara, hutan (adat) dijual/diserahkan kepada pemilik modal dieksploitasi tanpa memperhatikan hak dan kearifan lokal masyarakat adat di wilayah itu. Tak jarang, hal ini menyulut konflik antar masyarakat hukum adat dengan pengelola baru atas hutan adat mereka ${ }^{72}$. Dalam putusannya Mahkamah Konstitusi berpendapat ${ }^{73}$, kata negara dalam Pasal 1 angka 6, 4 Ayat (3), 5

70 Konvensi ILO No.169 Tahun 1989 mengenai masyarakat hukum adat. Mengenai pengakuan dan perlindungan tersebut diantaranya dalam Pasal 8.1 dengan memuat bahwa peraturan hukum nasional harus mempertimbangkan keberadaan dan eksistensi masyarakat adat. Dan Pasal 6 ayat (1) UU No. 39 tahun 1999 tentang HAM.

${ }^{71}$ Lihat Pengujian UU No. UU No. 5 tahun 1999 Tentang Kehutanan.

${ }^{72} \mathrm{http}: / /$ www.hukumonline.com/berita/baca/lt5194c9568b9f7/mk-tegaskan-hutan-adat-bukanmilik-negara, diakses 22 Maret 2015, Pkl. 20:24 WIB.

${ }^{73}$ Lihat Pertimbangan Hukum Putusan Mahkamah Konstitusi Nomor 35/PUU-X/2012, yaitu Terhadap hutan adat, wewenang negara dibatasi sejauh mana isi wewenang yang tercakup dalam hutan adat. Hutan adat (yang disebut pula hutan marga, hutan pertuanan, atau sebutan lainnya) berada dalam cakupan hak ulayat karena berada dalam satu kesatuan wilayah (ketunggalan wilayah) masyarakat hukum adat, yang peragaannya didasarkan atas leluri (traditio) yang hidup dalam suasana rakyat (in de volksfeer) dan mempunyai suatu badan perurusan pusat yang berwibawa dalam seluruh lingkungan wilayahnya. Para warga suatu masyarakat hukum adat memunyai hak membuka hutan ulayatnya untuk dikuasai dan diusahakan tanahnya bagi pemenuhan kebutuhan pribadi dan keluarganya. Dengan demikian, tidak dimungkinkan hak yang dipunyai oleh warga masyarakat hukum adat tersebut ditiadakan atau dibekukan sepanjang memenuhi syarat dalam cakupan pengertian kesatuan masyarakat hukum adat sebagaimana dimaksud dalam Pasal 18B ayat (2) UUD 1945. Setelah ditentukan pembedaan antara hutan negara, hutan hak (baik berupa hutan perseorangan maupun hutan adat yang tercakup dalam hak ulayat), maka tidak dimungkinkan hutan hak berada dalam wilayah hutan negara, atau sebaliknya hutan negara dalam wilayah hutan hak sebagaimana dinyatakan Pasal 5 ayat (2) dan Penjelasan Pasal 5 ayat (1) Undang-Undang a quo, serta hutan ulayat dalam hutan negara, sehingga menjadi jelas status dan letak hutan ulayat dalam kaitannya dengan pengakuan dan perlindungan kesatuan-kesatuan masyarakat hukum adat yang dijamin oleh Pasal 18B ayat (2) UUD 
Ayat (1) dan (2) beserta penjelasannya dalam Undang-Undang Nomor 41 Tahun 1999 tentang Kehutanan tidak memunyai kekuatan hukum mengikat $^{74}$. Maka implikasi pasca putusan tersebut, terdapat pemisahan atas ketentuan hutan negara dan hutan adat, dan oleh kementrian kehutanan diantaranya melanjutkan inventarisasi perda terkait masyarakat hukum adat, mempercepat penyelesaian RUU tentang Pengakuan dan Perlindungan Masyarakat Hukum Adat, Kemendagri untuk mendorong Pemda segera mendata keberadaan masyarakat hukum adat beserta wilayah adatnya ${ }^{75}$. Di samping itu berdasarkan keterangan yang didapatkan dari masyarakat hukum adat, para ahli dan para pihak yang terlibat Tim Inkuiri Nasional merekomendasikan :

$(1)^{76}$. Pemerintah pusat dan daerah hendaknya mempercepat pengukuhan masyarakat hukum adat dan hak-hak yang melekat padanya melalui peraturan perundang-undangan yang tepat mengacu kepada Putusan MK Nomor 35/PUU-X/2012. Negara harus segera menyusun dan mengambil langkah yang nyata, terukur, dan terjadwal untuk memulihkan hak-hak masyarakat hukum adat yang telah dilanggar, Proses pemulihan yang membutuhkan waktu tersebut tidak lantas menunda pemenuhan hak atas keadilan yang melekat pada diri masyarakat hukum adat; (2) Peta-peta indikatif wilayah masyarakat hukum adat yang disampaikan dalam DKU dapat menjadi acuan awal dalam penyelesaian tumpang tindih dan tata batas wilayah adat dan kawasan hutan. Penyelesaian ini direkomendasikan untuk terus dipantau kemajuan dari waktu kewaktu oleh pemerintah daerah dan dilaporkan ke Komnas HAM; (3). Kementerian Kehutanan RI segera memperbaiki batas-batas "luar" kawasan hutan melalui pelepasan wilayah pemukiman dan sawah-sawah serta penetapan batas "dalam" kawasan hutan yang mempertegas batas hutan negara, hutan milik termasuk hutan adat; (4) Pemerintah Daerah wajib melakukan konsultasi dan sosialisasi terlebih dahulu dengan masyarakat hukum adat sebelum penerbitan, perpanjangan atau berakhirnya izin lokasi dan izin usaha perusahaan di wilayah adat; (5) Semua pihak untuk mendalami dugaan penipuan dan

1945. Dengan demikian, hutan berdasarkan statusnya dibedakan menjadi dua yaitu hutan negara dan hutan hak. Adapun hutan hak dibedakan antara hutan adat dan hutan perseorangan/badan hukum. Ketiga status hutan tersebut pada tingkatan yang tertinggi seluruhnya dikuasai oleh negara.

${ }^{74}$ Lihat Putusan Mahkamah Konstitusi Nomor 35/PUU-X/2012, hlm. 185 - 186.

${ }^{75}$ Lihat Langkah Strategis Pengelolaan Hutan dan Mekanisme Penetapan Hutan Adat Pasca Terbitnya Putusan MK No. 35/PUU-X/2012 oleh Kementrian Kehutanan, 29 Agustus 2013.

${ }^{76}$ Wacana HAM, Edisi II/Tahun XII/2014, hlm. 8. 
manipulasi dalam proses pembebasan lahan masyarakat hukum adat untuk memperoleh berbagai perizinan perusahaan, untuk itu mendorong Kementerian Kehutanan RI segera memperbaiki sistem perizinan on line yang transparan; dan kepada KPK serta POLRI menindaklanjuti dengan penelitian atas indikasi manipulasi proses perizinan; (6) Kepolisian RI agar membuat Prosedur Operasi Standar dalam penanganan konflik sumber daya alam antara masyarakat hukum adat, pemerintah dan perusahaan, berperspektif hak asasi manusia berbasis gender ${ }^{77}$. Polri agar tidak melakukan kriminalisasi terhadap masyarakat hukum adat yang membela dan mempertahankan hak-hak adatnya dengan mengedepankan proses penegakan hukum yang akuntabel, yaitu mengutamakan pembuktian materiel dan substantif di atas pembuktian secara formil; (7) Untuk beberapa kasus yang sudah mulai terjadi konflik bersifat konflik horizontal antar masyarakat hukum adat berkaitan dengan batas wilayahnya, diperlukan langkah luar biasa untuk menghentikan pemberian ijin di wilayah masyarakat hukum adat tersebut, dan diarahkan untuk menyelesaikan pertentangan batas antara mereka dengan mengutamakan cara damai dan berkeadilan; (8) Pemerintah perlu memastikan terwujudnya pelayanan kesehatan, terutama terkait hak atas kesehatan ibu dan anak di kawasan yang berkonflik; (9) Program tanggung jawab perusahaan harus berbasis hak asasi manusia dan gender. Masyarakat hukum adat yang terdampak oleh kegiatan perusahaan, berhak atas program tanggung jawab perusahaan, bukan hanya menjadi penerima bantuan tapi mengedepankan pengembangan dan peningkatan kapasitas masyarakat hukum adat secara partisipatif, transparan, dan akuntabel; dan (10) Negara harus mengembalikan hak-hak ulayat dan meminta maaf kepada seluruh masyarakat adat dikawasan hutan yang telah mengalami pelanggaran HAM selama bertahun-tahun ${ }^{78}$.

77 Berdasarkan data yang dihimpun oleh Laporan bulanan Komnas HAM bulan Februari 2013, terdapat pelanggaran HAM di bidang Sengketa lahan 28 perkara, Sengketa ketenagakerjaan 28 perkara; Perusakan lingkungan 12 perkara yang dilakukan oleh koorporasi dan sengketa lahan sebanyak 13 perkara serta, 14 perkara terkait masyarakat adat.

78 Berdasarkan data yang dihimpun oleh Laporan bulanan Komnas HAM bulan Februari 2013, terdapat pelanggaran HAM yang dilakukan oleh Negara melalui kementerian/setingkat kementerian di antara yang paling tinggi yaitu Badan Pertanahan Nasional (BPN) dengan 9 dari total 28 laporan pelanggaran HAM yang dilakukan oleh Negara. 


\section{3) Kejelasan Masyarakat Adat Menegakan Haknya dalam Peradilan Konstitusi (Putusan Mahkamah Konstitusi Nomor 31/PUU-V/2007 ${ }^{\mathbf{7 9}}$ )}

Perlindungan yang harus diberikan Mahkamah Konstitusi dapat dilihat dalam pertimbangan hukum Putusan Nomor 31/PUU-V/2007, Mahkamah Konstitusi telah memberikan penafsiran terhadap Pasal 18B ayat $(2)^{80}$ UUD 1945 juncto Pasal 51 ayat (1) huruf b UU MK berkenaan dengan adatidaknya kedudukan hukum (legal standing) kesatuan masyarakat hukum adat, sebagai berikut: ${ }^{81}$

a) suatu kesatuan masyarakat hukum adat secara de facto masih hidup (actual existence), baik yang bersifat teritorial, geneologis, maupun yang bersifat fungsional, setidaknya-tidaknya mengandung unsur-unsur: i) adanya masyarakat yang warganya memiliki perasaan kelompok (ingroup feeling); ii) adanya pranata pemerintahan adat; iii) adanya harta kekayaan dan/atau benda-benda adat; iv) adanya perangkat norma hukum adat; dan v) khusus pada kesatuan masyarakat hukum adat yang bersifat teritorial juga terdapat unsur adanya wilayah tertentu.

b) suatu kesatuan masyarakat hukum adat beserta hak-hak tradisionalnya dipandang sesuai dengan perkembangan masyarakat apabila kesatuan masyarakat hukum adat tersebut: i) keberadaannya telah diakui berdasarkan undang-undang yang berlaku sebagai pencerminan perkembangan nilai-nilai yang dianggap ideal dalam masyarakat dewasa ini, baik undang-undang yang bersifat umum maupun bersifat sektoral, seperti bidang agraria, kehutanan, perikanan, dan lain-lain maupun dalam peraturan daerah; dan ii) Substansi hak-hak tradisional tersebut diakui dan dihormati oleh warga kesatuan masyarakat yang bersangkutan maupun masyarakat yang lebih luas, serta tidak bertentangan dengan hakhak asasi manusia.

c) Suatu kesatuan masyarakat hukum adat beserta hak-hak tradisionalnya sesuai dengan prinsip negara kesatuan masyarakat Indonesia apabila kesatuan masyarakat hukum adat tersebut tidak menggangu eksistensi Negara Kesatuan Republik Indonesia sebagai sebuah kesatuan politik dan kesatuan hukum, yaitu: i) keberadaannya tidak mengancam kedaulatan

79 Pengujian UU No. 31 Tahun 2007 tentang Pembentukan Kota Tual di Provinsi Maluku Lembaran Negara RI Tahun 2007 Nomor 97.

${ }^{80}$ (1) Negara mengakui dan menghormati satuan-satuan pemerintahan daerah yang bersifat khusus atau bersifat istimewa yang diatur dengan Undang-Undang; (2) Negara mengakui dan menghormati kesatuan-kesatuan masyarakat hukum adat serta hak-hak tradisionalnya sepanjang masih hidup dan sesuai dengan perkembangan masyarakat dan prinsip Negara Kesatuan Republik Indonesia, yang diatur dalam Undang-Undang;

${ }^{81}$ Lihat Putusan Nomor 31/PUU-V/2008 bertanggal 18 Juni 2008 melalui Website MK di: http://www.mahkamahkonstitusi.go.id/putusan/putusan_sidang_PUTUSAN\%2031\%20TU AL\%20dibaca\%2018\%20Juni\%202008.pdf. 
dan integritas Negara Kesatuan Republik Indonesia; ii) substansi norma hukum adatnya sesuai dan tidak bertentangan dengan peraturan perundang-undangan.

Dapat kita lihat dalam tabel mengenai syarat-syarat yang harus dipenuhi dalam mencakup menjadi pemohon yang sah (memiliki legal satnding) bagi kesatuan masyarakat hukum adat. ${ }^{82}$

\begin{tabular}{|c|c|c|}
\hline No & $\begin{array}{l}\text { Jenis } \\
\text { Persyaratan }\end{array}$ & Hal yang Harus Dipenuhi \\
\hline 1. & Formal & $\begin{array}{l}\text { 1. Undang-undang Nomor } 24 / 2003 \text {, Pasal } 51 \\
\text { ayat (1) huruf } \mathrm{b}^{83} \text {. Dokumen-dokumen } \\
\text { hukum yang sah disertakan. } \\
\text { 2. Peraturan Mahkamah Konstitusi Nomor } \\
\text { 06/PMK/2005 } 5^{84} \text {. }\end{array}$ \\
\hline 2. & Materiil & $\begin{array}{l}\text { 1. adanya jaminan konstitusional terhadap } \\
\text { hak atau kewenangan yang bersangkutan } \\
\text { dalam Pasal 18B ayat (2). } \\
\text { 2. adanya kerugian hak atau kewenangan } \\
\text { konstitusional (legal constitutional). } \\
\text { 3. adanya kerugian hak (perdata) yang } \\
\text { digambarkan secara faktual (sebagai } \\
\text { komplementer). }\end{array}$ \\
\hline
\end{tabular}

\section{4) Hak Politik dan HAM (Putusan Mahkamah Konstitusi Nomor 011- 017/PUU-I/2003)}

Dalam pengujian Undang-Undang No. 12 Tahun 2003 tentang Pemilihan Umum Anggota DPR, DPD, dan DPRD, pemohon mempersoalkan pasal 60 huruf g yang berbunyi: bukan bekas anggota organisasi terlarang Partai Komunis lndonesia (PKI), termasuk organisasi massa, atau bukan orang yang terlibat langsung ataupun tak langsung dalam G.30.S./PKI. atau organisasi terlarang lainnya.

Dalam pertimbangannya Mahkamah Konstitusi menilai bahwa hak dipilih dan memilih (right to vote and right to candidate) adalah hak warga Negara yang merupakan lingkup dari HAM, dan pembatasan hak partisipasi

\footnotetext{
${ }^{82}$ Hendra Nurtjahjo dan Fokky Fuad, Legal Standing Kesatuan Masyarakat Hukum Adat Dalam Berperkara di Mahkamah Konstitusi, (Jakarta: Salemba Humanika, 2010), hlm 99

${ }^{83}$ Kesatuan masyarakat hukum adat sepanjang masih hidup dan sesuai dengan perkembangan masyarakat dan prinsip Negara Kesatuan Republik Indonesia yang diatur dalam undangundang.

${ }^{84}$ Tentang pedoman beracara dalam pengujian undang-undang di Mahkamah Konstitusi.
} 
politik $^{85}$ bertentangan dengan Undang-Undang Dasar $1945^{86}$ dan jika kemudian dilanggar/terjadinya diskriminasi ${ }^{87}$ merupakan pelanggaran atas $\mathrm{HAM}^{88}$. Dalam hal ini Hak politik dalam sistem demokrasi adalah salah satu hal utama yang harus dipenuhi, sebab demokrasi itu sendiri menuntut pelibatan warga negara yang seluas-luasnya, dengan prinsip partisipatif dan non-diskriminasi, maka demokrasi biasanya adalah demokrasi representatif di mana pemerintah dengan wakil-wakil rakyat terpilih secara bebas ${ }^{89}$.

\section{5) Informasi Publik, Privasi dan HAM (Putusan Mahkamah Konstitusi No 6-13-20/PUU-VIII/2010)}

Putusan Mahkamah Konstitusi berikutnya terkait HAM, namun dalam perspektif informasi publik yang merupakan bagian dari HAM itu sendiri. perkara permohonan pengujian Undang-Undang Nomor 11 Tahun 2008 tentang Informasi dan Transaksi Elektronik terhadap Undang-Undang Dasar Negara Republik Indonesia Tahun 1945.

85 Lihat Pertimbangan Mahkamah Konstitusi dalam putusan; Menimbang bahwa memang Pasal 28J ayat (2) Undang-Undang Dasar Negara Republik Indonesia Tahun 1945 memuat ketentuan dimungkinkannya pembatasan hak dan kebebasan seseorang dengan undangundang, tetapi pembatasan terhadap hak-hak tersebut haruslah di dasarkan atas alasanalasan yang kuat, masuk akal dan proporsional serta tidak berkelebihan. Pembatasan tersebut hanya dapat dilakukan dengan maksud "semata-mata untuk menjamin pengakuan serta penghormatan atas hak dan kebebasan orang lain dan untuk memenuhi tuntutan yang adil sesuai dengan pertimbangan moral, nilai-nilai agama, keamanan, dan ketertiban umum dalam suatu masyarakat demokratis"; tetapi pembatasan hak dipilih seperti ketentuan Pasal 60 huruf g Undang-undang Nomor 12 Tahun 2003 Tentang Pemilihan Umum tersebut justru karena hanya menggunakan pertimbangan yang bersifat politis.

${ }^{86}$ Lihat Pasal 28 C ayat (2), Pasal 28 D ayat (1), Pasal 28 D ayat (3), dan Pasal 28 I ayat (3) UUD 1945

${ }^{87}$ Lihat Article 21 Universal Declaration of Human Rights yang menyatakan: 1. Everyone has the right to take part in the government of his country, directly or through freely chosen representatives.; 2. Everyone has the right of equal access to public service in his country.; 3. The will of people shall be the basis of the authority of government; this will shall be expressed in periodic and genuine elections which shall be by universal and equal suffrage and shall be held by secret vote or by equivalent free voting procedures.

${ }^{88}$ Lihat pertimbangan hukum Mahkamah Konstitusi dalam putusannya: Menimbang, bahwa Undang-Undang Dasar Negara Republik Indonesia Tahun 1945 melarang diskriminasi sebagaimana dinyatakan dalam Pasal 27 ayat (1), Pasal 28 D ayat (1), Pasal 28 I ayat (2). Pasal 1 ayat (3) Undang-Undang Nomor 39 Tahun 1999 tentang Hak Asasi Manusia sebagai penjabaran ketentuan Pasal 27 dan Pasal 28 Undang-Undang Dasar Negara Republik Indonesia Tahun 1945 tidak membenarkan diskriminasi berdasarkan perbedaan agama, suku, ras, etnik, kelompok, golongan status sosial, status ekonomi, jenis kelamin, bahasa, keyakinan politik.

${ }^{89}$ Arend Lijphart : Pola - pola Mayoritas dan pemerintahan konsensus di abad ke-21, dalam Satya Arinanto : Politik hukum 1, hlm 31. 
Dalam gugatan tersebut bahwa pemohon yang merupakan seorang advokat merasa akan dilanggar privasinya atas berlakunya Pasal 31 ayat (4) ${ }^{90}$ UU Nomor 11 Tahun 2008 Informasi dan Transaksi Elektronik tentang yang mengamanatkan pengaturannya melalui suatu Peraturan Pemerintah (PP). Kondisi demikian sangat kontradiktif dengan adanya perlindungan yang diberikan UU Nomor 18 Tahun 2003 tentang Advokat ${ }^{91}$, yang memberikan perlindungan atas penyadapan terkait hubungannya dengan klien. Pemohon mendalilkan bahwa:

Pasal 31 Undang-Undang a quo memuat dua ketentuan mengenai penyadapan, yang pertama adalah menyatakan bahwa penyadapan adalah sebuah perbuatan ilegal yang dilarang dan bagi siapapun yang melakukannya akan diganjar hukuman pidana. sedangkan muatan kedua mengatur mengenai penyadapan yang dapat dilakukan (legal) jika dalam rangka penegakan hukum atas permintaan kepolisian, kejaksaan, dan/atau institusi penegak hukum lainnya yang ditetapkan berdasarkan Undang-Undang; Bahwa mandat Peraturan Pemerintah dalam dalam ayat (4) tersebut dalam kaitanya dengan Undang-Undang a quo, adalah untuk mengatur mengenai tata cara permintaan dan pemberian rekaman informasi (yang dikirim dan/atau diterima) yang disalurkan melalui jaringan telekomunikasi dalam bentuk apapun oleh penyelenggara jasa telekomunikasi;

Dengan demikian pemohon menganggap akan pemohon mendalilkan ketentuan tata cara mengenai penyadapan tidak seharusnya diatur lebih lanjut dalam Peraturan Pemerintah melainkan harus diatur melalui UndangUndang. Pemohon beralasan bahwasanya pembatasan terhadap HAM hanya dapat dilakukan menggunakan formula pengaturan UU. Pengaturan penyadapan dalam PP tidak akan cukup menampung artikulasi pengaturan penyadapan; Pemohon juga mendalilkan dua putusan Mahkmah Konstitusi yaitu: (1) Putusan Mahkamah Konstitusi dalam Perkara 006/PUU-I/2003 ${ }^{92}$

${ }^{90}$ Ketentuan lebih lanjut mengenai tata cara intersepsi sebagaimana dimaksud pada ayat (3) diatur dengan Peraturan Pemerintah.

${ }^{91}$ Pasal 19 ayat (2) UU Nomor 18 Tahun 2003 tentang Advokat, "Advokat berhak atas kerahasiaan hubungannya dengan Klien, termasuk perlindungan atas berkas dan dokumennya terhadap penyitaan atau pemeriksaan dan Perlindungan terhadap penyadapan atas komunikasi elektronik Advokat";

92 "hak privasi bukanlah bagian dari hak-hak yang tidak dapat dikurangi dalam keadaan apapun (non-derogable rights), sehingga negara dapat melakukan pembatasan terhadap pelaksanaan hak-hak tersebut dengan menggunakan Undang-Undang, sebagaimana diatur dalam Pasal 28J ayat (2) Undang-Undang Dasar Negara Republik Indonesia Tahun 1945." Dan "untuk mencegah kemungkinan penyalahgunaan kewenangan untuk penyadapan dan perekaman Mahkamah Konstitusi berpendapat perlu ditetapkan perangkat peraturan yang mengatur syarat dan tata cara penyadapan dan perekaman dimaksud". 
dan (2) Putusan Mahkamah Konstitusi dalam Perkara 012-016-019/PUUIV/2006 ${ }^{93}$. Mahkamah Konstitusi kemudian memutuskan bahwa pengaturan mengenai HAM tidak dapat dilakukan dalam PP melainkan diamanatkan dalam suatu UU sebagaimana dalam putusan sebelumnya. Bahwa pembatasan terhadap hak asasi manusia yang merupakan derogable rights hanya dapat dibatasi dengan ketentuan UU. Karena bahwa PP tidak dapat mengatur pembatasan HAM. Bentuk Peraturan Pemerintah hanya merupakan pengaturan administratif ${ }^{94}$ dan tidak memiliki kewenangan untuk menampung pembatasan atas HAM.

Menurut MK, akibat ketiadaan aturan tunggal tentang hukum acara dan/atau tata cara penyadapan telah menyebabkan terancamnya hak atas privasi warga negara dalam negara-negara hukum modern di dunia. MK menekankan perlu dibuat sebuah undang-undang khusus yang mengatur tentang penyadapan secara umumnya, hingga tata cara penyadapan untuk masing-masing lembaga yang berwenang ${ }^{95}$.

\section{6) Hak atas Hubungan Kerja yang Layak Putusan Mahkamah Konstitusi No 27/PUU-IX/2011}

Bentuk perlindungan Mahkamah Konstitusi terhadap eksistensi HAM bagi warga Negara tercermin dalam putusannya dalam Undang-Undang Nomor 13 Tahun 2003 tentang Ketenagakerjaan. Dalam permohonannya pemohon yaitu Perkumpulan Aliansi Petugas Pembaca Meter Listrik Indonesia (AP2ML) Provinsi Jawa Timur mendalilkan Pasal 59 dan Pasal 64 Undang-Undang Nomor 13 Tahun 2003 tentang Ketenagakerjaan tidak

93 "Mahkamah memandang perlu untuk mengingatkan kembali bunyi pertimbangan hukum Mahkamah dalam Putusan Nomor 006/PUU-I/2003 tersebut oleh karena penyadapan dan perekaman pembicaraan merupakan pembatasan terhadap hak-hak asasi manusia, di mana pembatasan demikian hanya dapat dilakukan dengan undang-undang, sebagaimana ditentukan oleh Pasal 28J Ayat (2) UUD 1945. Undang-undang dimaksud itulah yang selanjutnya harus merumuskan, antara lain, siapa yang berwenang mengeluarkan perintah penyadapan dan perekaman pembicaraan dan apakah perintah penyadapan dan perekaman pembicaraan itu baru dapat dikeluarkan setelah diperoleh bukti permulaan yang cukup, yang berarti bahwa penyadapan dan perekaman pembicaraan itu untuk menyempurnakan alat bukti, ataukah justru penyadapan dan perekaman pembicaraan itu sudah dapat dilakukan untuk mencari bukti permulaan yang cukup. Sesuai dengan perintah Pasal 28J Ayat (2) UUD 1945, semua itu harus diatur dengan undang-undang guna menghindari penyalahgunaan wewenang yang melanggar hak asasi.

${ }^{94}$ Lihat Pasal 1 angka 5 UU No.12 Tahun 2011 tentang Pembentukan Peraturan Perundangundangan, bahwa Peraturan Pemerintah adalah Peraturan Perundang-undangan yang ditetapkan oleh Presiden untuk menjalankan Undang-Undang sebagaimana mestinya. Dengan demikian PP tidak dapat mengatur lebih jauh dari apa yang telah diamanatkan oleh UU dan bersifat teknis pelaksanaan.

${ }^{95}$ Muhtadi, Antara Penyadapan dan Perlindungan Hak Atas Informasi, (Jakarta: Jurnal Pusat Kajian Konstitusi dan Perundang-undangan Universitas Islam Indonesia, 2012 hlm. 155. 
sesuai dengan Pasal 27 ayat (2) ${ }^{96}$, Pasal 28D ayat (2) ${ }^{97}$ dan Pasal 33 ayat (1) ${ }^{98}$ UUD 1945.

Dalam praktik ketenagakerjaan yang dianut dalam undang-undang yang dimohonkan sangat kental dengan praktik perbudakan modern, karena status pekerja bukanlah sebagai subjek perjanjian kerja melainkan sebagai objek/komoditas perdagangan. Karena sistem Perjanjian Kerja Waktu Tertentu (PKWT) dan sistem outsourching yang menjadi pokok pengujian, maka Mahkamah Konstitusi memberikan dua model yaitu Pertama, dengan menyaratkan agar perjanjian kerja antara pekerja/buruh dengan perusahaan yang melaksanakan pekerjaan outsourching tidak berbentuk PKWT, melainkan berbentuk "perjanjian kerja waktu tidak tertentu". Kedua, menerapkan prinsip pengalihan tindakan perlindungan bagi pekerja/buruh (Transfer of Undertaking Protection of Employment atau TUPE) yang bekerja pada perusahaan yang melaksanakan pekerjaan outsourching. Sesuai dalam putusan Mahkamah Konstitusi Putusan Nomor 12/PUU-I/2003 ${ }^{99}$. Dengan konstruksi pemikiran yang demikian maka, Mahkamah Konstitusi memutuskan bahwa justru dalam Pasal 65 dan 66 yang terkait dengan pasal yang dimohonkan dalam UU Nomor 13 Tahun 2003 tentang Ketenagakerjaan justru bertentangan dengan UUD 1945.

96 "Tiap-tiap warga negara berhak atas pekerjaan dan penghidupan yang layak bagi kemanusiaan".

97 "Setiap orang berhak untuk bekerja serta mendapat imbalan dan perlakuan yang adil dan layak dalam hubungan kerja".

98 "Perekonomian disusun sebagai usaha bersama berdasar atas asas kekeluargaan".

99 Lihat Pertimbangan Mahkamah Konstitusi yang diputus tanggal 28 Oktober 2004 "Menimbang bahwa berdasarkan ketentuan tersebut, maka dalam hal buruh dimaksud ternyata dipekerjakan untuk melaksanakan kegiatan pokok, tidak ada hubungan kerja dengan perusahaan penyedia jasa pekerja/buruh bukan merupakan bentuk usaha berbadan hukum, maka demi hukum status hubungan kerja antara pekerja/buruh dan perusahaan penyedia jasa beralih menjadi hubungan kerja antara pekerja/buruh dengan perusahaan pemberi pekerjaan. Oleh karena itu, dengan memperhatikan keseimbangan yang perlu dalam perlindungan terhadap pengusaha, buruh/pekerja dan masyarakat secara selaras, dalil para pemohon tidak cukup beralasan. Hubungan kerja antara buruh dengan perusahaan penyedia jasa yang melaksanakan pekerjaan pada perusahaan lain, sebagaimana diatur dalam Pasal 64 sampai dengan Pasal 66 Undang-Undang a quo, mendapat perlindungan kerja dan syarat-syarat yang sama perlindungan kerja dan syarat-syarat kerja pada perusahaan pemberi pekerjaan atau sesuai dengan peraturan perundang-undangan yang berlaku. Oleh karenanya, terlepas dari jangka waktu tertentu yang mungkin menjadi syarat perjanjian kerja demikian dalam kesempatan yang tersedia maka perlindungan hak-hak buruh sesuai dengan aturan hukum dalam UU Ketenagakerjaan, tidak terbukti bahwa hal itu menyebabkan sistem outsourching merupakan modern slavery dalam proses produksi". 


\section{Faktor Penting Perlindungan HAM Kontemporer di Indonesia}

Luas dan spesifiknya mengenai pengaturan $\mathrm{HAM}^{100}$ di Indonesia menimbulkan konsekuensi peran negara yang dituntut untuk memberikan perlindungan HAM bagi warga negara. Untuk melakukan perlindungan dan penegakan HAM, salah satu instrumen penting yaitu tegaknya kekuasaan kehakiman yang mandiri dan independen ${ }^{101}$.

Saat ini bentuk kekuasaan kehakiman di Indonesia dijalankan oleh dua kaki peradilan yaitu dalam lingkup Mahkamah Agung dan lingkup peradilan dibawahnya serta oleh Mahkamah Konstitusi ${ }^{102}$. Namun, pemahaman terpenting dalam lingkup kekuasaan kehakiman yaitu adanya independensi dan imparsialitas dari lembaga peradilan dalam menegakan keadilan dan HAM. Jaminan konstitusional independensi yudisial dalam ketentuan internasional antara lain diatur dalam Pasal 10 Deklarasi Umum Hak Asasi Manusia (Universal Declaration of Human Rights) PBB.

"Everyone is entitled in full equality to a fair and public hearing by an independent and impartial tribunal, in the determination of his rights and abligations and of any criminal charge against him." 103

Sehingga makna yang dikandung dalam Kekuasaan kehakiman (judicial power) adalah kekuasaan negara yang merdeka untuk menyelenggarakan peradilan guna menegakkan hukum dan keadilan berdasarkan Pancasila, demi terselenggaranya Negara Hukum Republik Indonesia, ${ }^{104}$ dan dijalankan oleh badan-badan peradilan di lingkungan MA

100 Lihat Pasal 28A-28J UUD 1945, diantaranya hak atas hidup dan penghidupan, hak membentuk keluarga, hak atas perlakuan yang asil, hak atas pekerjaan, hak untuk turut serta dalam pemerintahan, hak beragama, hak atas kewarganegaraan, hak atas keyakinan hati nurani, hak berserikat, hak berkomunikasi, hak atas perlindungan diri dari ketakutan, hak untuk bebas dari ketakutan, hak bebas dari penyiksaan, penghukuman atau perlakuan kejam, dan tidak manusiawi, hak atas kehidupan yang layak, hak atas persamaan di hadapan hukum, hak atas jaminan sosial, hak atas kepemilikan, hak untuk bebas dari diskriminasi, hak identitas adat dan budaya, kewajiban negara dalam menjamin perlindungan, pemajuan dan penegakan HAM, kewajiban setiap orang untuk menghormati HAM, kewajiban setiap orang untuk menghormati HAM, kewajiban setiap orang untuk tunduk kepada pembatasan yang ditetapkan dengan undang-undang.

${ }^{101}$ Lihat Pasal 24 ayat (1) UUD 1945: Kekuasaan kehakiman merupakan kekuasaan yang merdeka untuk menyelenggarakan peradilan guna menegakkan hukum dan keadilan.

102 Lihat Pasal 24 ayat (2) UUD 1945: Kekuasaan kehakiman dilakukan oleh sebuah Mahkamah Agung dan badan peradilan yang berada dibawahnya dalam lingkungan peradilan umum, lingkungan peradilan agama, lingkungan peradilan militer, lingkungan peradilan tata usaha negara, dan oleh sebuah Mahkamah Konstitusi.

103 (Setiap orang, dalam persamaan yang penuh, berhak atas pengadilan yang adil dan terbuka oleh pengadilan yang bebas dan tidak memihak, dalam menetapkan hak dan kewajibankewajibannya serta dalam setiap tuntutan pidana yang dijatuhkan kepadanya).

${ }^{104}$ Lihat Pasal 1 Undang-undang Nomor 48 Tahun 2009 tentang Kekuasaan Kehakiman. 
dan oleh sebuah Mahkamah Konstitusi, ${ }^{105}$ dengan kewenangan dan fungsi masing-masing.

Pentingnya independen atau kemandirian tersebut dilekatkan dengan kekuasaan kehakiman, maka yang dimaksudkan adalah suatu kondisi yang menunjukkan kehendak yang bebas atau a freedom and indepedency judiaciary ${ }^{106}$ yang tidak terbatas dalam organ (struktural) dan fungsional ${ }^{107}$ sebagaimana doktrin separation of power, melainkan otonomi melekat pada setiap diri hakim atau personal indepedence ${ }^{108}$ yang menerangkan sebagai the terms and conditions of judicial service are adequately secured, so as to ensure that individual judges are not subject to executive control, termasuk didalamnya kemampuan hakim dalam membuat putusan sebagai mahkota profesionalitas yang tertinggi, atau sepadan dengan substantive independence, ${ }^{109}$ yang bermakna that in the discharge of his judicial function, a judge is subject to nothing but the law and the commands of his conscience termasuk pengaruh, ketakutan dan keberpihakan ${ }^{110}$ dari their colleagues and superiors. ${ }^{11}$

Sedangkan kemandirian yang pertama sebagai implementasi doktrin pemisahan kekuasaan adalah terkait erat dengan outonomy and collective independence vis-a-vis the Executive. Kategorisasi demikian sebagaimana diungkapkan Shimon Shetreet dengan menambahkan internal indepedence bagi para hakim dalam bertindak. ${ }^{12}$ Keberadaan lembaga peradilan di Indonesia saat ini sangat dibutuhkan dan menjadi sangat fundamental dalam

105 Lihat Pasal 24 UUD Tahun 1945 jo Pasal 2 Undang-undang Nomor 48 Tahun 2009 Tentang Kekuasaan Kehakiman.

106 Bambang Widjoyanto, Kebebasan Kekuasaan Hakim Prasyarat Wujudkan Supremasi Hukum, dalam Ari Muhammad Arief, et.all. (penyunting), Position Paper Menuju Idependensi Kekuasaan Kehakiman, KRHN, ICEL dan LeIP, Jakarta, 1999, hlm. xiii.

${ }^{107}$ Lihat Dasar Menimbang huruf (a) Keputusan Ketua MA RI Nomor KMA/096/SK/X/2006 tanggal 19 Oktober 2006 tentang Tanggung Jawab Ketua Pengadilan Banding Dan Ketua Pengadilan Tingkat Pertama Dalam Melakukan Tugas Pengawasan.

${ }^{108}$ International BAR Association Code of Minimum Standards of Judicial Independence, The Jerusalem Approved Standars as adopted in the plenary Session of the $19^{\text {th }}$ IBA Blienial Conference held On Friday, $22^{\text {nd }}$ October 1982, in New Delhi, India, Chapter A, Article 1 (b).

${ }^{109}$ Ibid., Article 1 (c).

${ }^{110}$ Firmansyah Arifin, Komisi Yudisial Pengawal Reformasi Peradilan Mendayung Diantara Simpati dan Resistensi, dalam, Komisi Yudisial, Bunga Rampai Komisi Yudisial dan Reformasi Peradilan, (Jakarta: Komisi Yudisial, 2007), hlm. 45.

111 Universal Declaration on The Independence of Justice, Chapter II, Article 2 (03), lihat juga Jimly Asshidiqie, Struktur Ketatanegaraan Indonesia Setelah Perubahan Keempat UUD Tahun 1945, dalam BPHN, Seminar Pembangunan Hukum Nasional VIII, (Jakarta: BPHN Dep. Kehakiman dan HAM, 2003), hlm. 30.

112 Rifqi S. Assegaf dan Josi Khatarina, Membuka Ketertutupan Pengadilan, (Jakarta: Lembaga Kajian dan Advokasi untuk Independensi Peradilan (LeIP), 2005), hlm. vii. 
melakukan perlindungan HAM. Sebagaimana kita ketahui perlindungan HAM saat ini banyak dilakukan oleh lembaga-lembaga peradilan ${ }^{113}$.

Independensi kekuasaan kehakiman sangat diperlukan untuk menjamin hak asasi manusia dan mempertahankan keadilan yang menjadi unsur penting dalam negara demokrasi, antara demokrasi dan hukum tidak dipahami sebagai dua entitas yang contradictio in terminis di mana keduanya bisa berada dalam suasana hidup yang berdampingan secara damai (peacefull co-existance) tanpa salah satu diunggulkan dari yang lainya karenasemua penting dalam gagasan negara modern ${ }^{114}$. Sir Ninian Stephen dalam J Djohansyah mengemukakan pengertian Independensi dengan cara menjelaskan apa yang dimaksud istilah suatu kekuasaan kehakiman yang independen yaitu " $a$ judiciary which dispenses justice according to law without regard to the policies and inclinations of the goverment of the day" yang artinya suatu peradilan yang menjalankan keadilan menurut hukum tanpa pengaruh dari kebijakan dan tekanan pemerintah pada saat itu. ${ }^{115}$

Independensi kekuasaan kehakiman diyakini sebagai sarana yang efektif bagi tercapainya keadilan dalam bentuk jaminan perlindungan warga negara dari tindakan melawan hukum atau tindakan represif dari pihak penguasa $^{116}$. Dengan demikian ketika independensi hakim dan kekuasaan kehakiman maka akan tegaknya pula perlindungan HAM oleh lembaga peradilan, dan sangat ditentukan juga adanya kebebasan hakim dan imparsialitas. Urgenitas kebebasan hakim melekat pada indiviu hakim merupakan cermin kemandirian hakim dalam memeriksa dan memutus perkara bebas dari intervensi pihak mana pun termasuk kolega hakim (independensi substantif) maupun majelis hakim (independensi personal). Pranata dissenting opinion, menjadi alat uji kemampuan dan penguasaan ilmu dan teori hukum yang menjadi landasan penerapan hukum secara objektif dan adil. Secara filosofis dissenting opinion merupakan perwujudan prinsip kebebasan hakim secara individual dan melalui instrumen tersebutlah

113 Dalam berbagai putusan Mahkamah Konstitusi dan Mahkamah Agung dan peradilan dibawahnya, yaitu putusan Mahkamah Konstitusi dalam pengujian Pasal 28 dan 111 UU No. 42 Tahun 2008 tentang Pemilihan Umum Presiden dan Wakil Presiden ${ }^{113}$, Putusan Mahkamah Konstitusi Nomor 47-81/PHPU.A/VII/2009, Putusan Mahkamah Konstitusi Nomor 35/PUU-X/2012, Putusan Mahkamah Konstitusi Nomor 31/PUU-V/2007, Putusan Mahkamah Konstitusi Nomor 011-017/PUU-I/2003, Putusan Mahkamah Konstitusi No 613-20/PUU-VIII/2010, Putusan Mahkamah Konstitusi No 27/PUU-IX/2011.

114 A Ahsin Thohari, Demokrasi sekaligus Nomokrasi, Harian Kompas edisi Jumat 7 November 2003, hlm. 4.

115 J.Djohansyah, Reformasi Mahkamah Agung Menuju Independensi Kekuasaan Kehakiman, (Jakarta: Kesaint Blanc, 2008), hlm 136.

${ }^{116}$ Ismail Suny, Pembagian Kekuasaan Negara, (Jakarta: Aksara baru, 1978), hlm 21. 
setiap hakim bebas menentukan sikapnya dalam memutus perkara diperkuat rasionalitas-doktrinal dan hati nuraninya ${ }^{117}$.

Putusan MK dengan register nomor 005/PUU-IV/2006 dapat menjadi rujukan untuk mendalami kekuasaan kehakiman dan kebebasan hakim yang merdeka menurut UUD 1945 Pengujian Undang-Undang Republik Indonesia Nomor 22 Tahun 2004 tentang Komisi Yudisial dan Pengujian UndangUndang Republik Indonesia Nomor 4 Tahun 2004 tentang Kekuasaan Kehakiman yang diajukan oleh Para Hakim Agung ${ }^{118}$ di Mahkamah Agung yakni pada Pasal 1 angka 5, Pasal 20, Pasal 21, Pasal 22 ayat (1) huruf e dan ayat (5), Pasal 23 ayat (2) dan ayat (3) serta ayat (5), Pasal 24 ayat (1) dan Pasal 25 ayat (3) dan ayat (4) Undang-undang Nomor 22 Tahun 2004, serta Pasal 34 ayat (3) Undang-undang Nomor 4 Tahun 2004 ${ }^{119}$, sepanjang yang menyangkut Hakim Agung dan Hakim Mahkamah Konstitusi, bertentangan dengan Pasal 24B dan Pasal 25 Undang-Undang Dasar Negara Republik Indonesia Tahun 1945 di mana pasal-pasal tersebut menurut para hakim berpotensi menghancurkan independensi Hakim Agung yang dijamin UUD $1945^{120}$.

117 J.Pajar Widodo, Menjadi Hakim Progresif, (Bandar lampung: Indepth Publishing, 2013), hlm. 9.

${ }^{118}$ Hakim Agung pada Mahkamah Agung RI pada saat itu: Prof. Dr. Paulus Effendi Lotulung, SH.; Drs.H. Andi Syamsu Alam, SH.MH.; Drs.H. Ahmad Kamil, SH.M.Hum.; H. Abdul Kadir Mappong, SH.; Iskandar Kamil, SH.; Harifin A. Tumpa, SH. MH.; Prof. Dr. H. Muchsin, SH. ; Prof. Dr. Valerine J.L.K., SH.MA.; H. Dirwoto, SH.; DR. H. Abdurrahman, SH.MH.; Prof. Dr. H. Kaimuddin Salle, SH.MH. ; Mansur Kartayasa, SH.MH.; Prof. Rehngena Purba, SH.MS.; Prof. Dr. H.M. Hakim Nyak Pha, SH.DEA.; Drs. H. Hamdan, SH.MH.; H.M. Imron Anwari, SH.SpN.MH; TITi Nurmala Siahaan Siagian, SH.MH.; Widayatno Sastro Hardjono, SH.MSc.; Moegihardjo, SH.; H. Muhammad Taufiq, SH.; H. R. Imam Harjadi, SH.; Abbas Said, SH.; Andar Purba, SH.; Djoko Sarwoko, SH.MH.; I Made Tara, SH.; Atja Sondjaja, SH.; H. Imam Soebechi, SH. MH.; Marina Sidabutar, SH.; H. Usman Karim, SH.; Drs. H. Habiburrahman, M.Hum.; M. Bahaudin Quadry, SH.

119 Telah diubah menjadi UU No. 48 Tahun 2009 tentang kekuasaan Kehakiman.

${ }^{120}$ Putusan MK register nomor 005/PUU-IV/2006 dalam Dasar Pertimbangan, hlm 169, yaitu: Independensi peradilan dan independensi hakim merupakan unsur esensial dari negara hukum atau rechtsstaat (rule of law) tersebut. Oleh karena pentingnya prinsip ini, maka konsepsi pemisahan kekuasaan di antara kekuasaan eksekutif, legislatif, dan yudikatif, serta konsepsi independensi peradilan, telah dipandang sebagai konsepsi yang fundamental sehingga diangkat sebagai salah satu unsur utama dari konstitusi, dan merupakan jiwa dari konstitusi itu sendiri. Bahkan, ketika UUD 1945 belum diubah pun, di mana ajaran pemisahan kekuasaan tidak dianut, prinsip pemisahan dan independensi kekuasaan kehakiman sudah ditegaskan, dan hal itu sudah tercermin dalam Pasal 24 dan Penjelasan Pasal 24 tersebut. Sekarang setelah UUD 1945 diubah dari perubahan pertama hingga keempat, di mana cabang-cabang kekuasaan negara dipisahkan berdasarkan prinsip checks and balances, terutama dalam hubungan antara legislatif dengan eksekutif, maka pemisahan kekuasaan yudikatif dari pengaruh cabang-cabang kekuasaan lainnya semakin dipertegas sehingga independensi kekuasaan kehakiman di samping bersifat 
Selain itu UUD 1945 menentukan bahwa hak konstitusional warga negara yang dijamin dalam UUD 1945 meliputi berbagai aspek kehidupan, baik sipil, politik, ekonomi, maupun sosial. Di bidang hukum, hak-hak konstitusional warga negara meliputi:

a. hak kesamaan di hadapan hukum (equality before the law) sebagaimana dijamin dalam Pasal 27 ayat (1) 121 ;

b. hak atas pengakuan, jaminan, perlindungan, dan kepastian hukum yang adil, serta hak atas perlakuan yang sama dihadapan hukum, sebagaimana ditentukan dalam Pasal 28D ayat (1) ${ }^{122}$;

c. hak perlindungan diri pribadi sebagaimana diatur dalam Pasal 28D ayat (1) ${ }^{123}$;

Bahkan, Pasal 28I ayat (1) UUD 1945 menempatkan "hak untuk diakui sebagai pribadi di hadapan hukum", merupakan salah satu hak yang tidak dapat dikurangi dalam keadaan apapun. Berdasarkan ketentuan UUD 1945 dapat dilihat bahwa hak kesamaan dihadapan hukum atau hak atas perlakuan yang sama di hadapan hukum adalah hak konstitusional setiap warga negara. Perlakuan yang sama di hadapan hukum juga berarti bahwa tiap warga negara harus diakui sebagai subyek hukum penyandang hak dan kewajiban yang memiliki kebebasan dan tanggung jawab untuk melakukan perbuatan hukum. Hal ini kemudian menjadi cerminan di samping dibutuhkan adanya pengaruh sentral hakim, terdapat faktor penunjang terpenuhinya HAM bagi warga Negara, yaitu adanya bantuan hukum. UUD 1945 menentukan bahwa pemenuhan hak atas perlakuan yang sama di hadapan hukum, hak atas pengakuan sebagai pribadi di hadapan hukum serta hak atas keadilan melalui bantuan hukum adalah tanggung jawab negara ${ }^{124}$. Bahkan, Undang-Undang Kekuasaan Kehakiman Nomor 48 Tahun 2009 pada Pasal 37 sudah menyatakan "Setiap orang yang tersangkut perkara berhak memperoleh bantuan hukum". Selain itu, Undang-Undang Nomor 18 Tahun 2003 tentang Advokat juga mewajibkan para advokat untuk menangani perkara pro bono, dan sangat berkaitan dengan fungsinya

fungsional juga bersifat struktural yaitu dengan diadopsinya kebijakan satu atap sebagaimana diatur dalam Pasal 13 ayat (1) UUKK.

121 "Segala warga negara bersamaan kedudukannya di dalam hukum dan pemerintahan dan wajib menjunjung hukum dan pemerintahan itu dengan tidak ada kecualinya."

122 "Setiap orang berhak atas pengakuan, jaminan, perlindungan, dan kepastian hukum yang adil serta perlakuan yang sama di hadapan hukum."

123 "Setiap orang berhak atas perlindungan diri pribadi, keluarga, kehormatan, martabat, dan harta benda yang di bawah kekuasaannya, serta berhak atas rasa aman dan perlindungan dari ancaman ketakutan untuk berbuat atau tidak berbuat sesuatu yang merupakan hak asasi manusia."

${ }^{124}$ Lihat Pasal 18 (Ayat 4) UU No. 39 Tahun 1999 tentang HAM: Setiap orang yang diperiksa berhak mendapatkan bantuan hukum sejak saat penyidikan sampai adanya putusan pengadilan yang telah memperoleh kekuatan hukum tetap. 
menegakkan $\mathrm{HAM}^{125}$.Mengingat pentingnya peran bantuan hukum dalam mewujudkan cita negara hukum ${ }^{126}$. Paling tidak terdapat empat fungsi yang dijalankan melalui pemberian bantuan hukum. Pertama, dengan adanya bantuan hukum akan terwujud persamaan di hadapan hukum. Proses hukum yang fair dan imparsial hanya akan terjadi apabila pihak-pihak yang bersengketa memiliki posisi dan kekuatan yang seimbang, terutama dari sisi pengetahuan dan keterampilan hukum. Kedua, apabila proses hukum berjalan secara fair dan impartial, semua kebenaran materiil harapannya dapat terungkap. Dengan adanya posisi dan kekuatan yang seimbang, manipulasi dan hegemoni atas fakta dan kebenaran dapat dicegah. Dengan demikian, bantuan hukum berfungsi memperkuat upaya menegakkan keadilan substansial melalui proses hukum yang fair dan impartial.

Ketiga, bantuan hukum memberikan ruang interaksi antara para ahli dan profesi hukum dengan masyarakat umum. Interaksi itu akan menumbuhkan pemahaman dan kesadaran bagaimana memposisikan suatu aturan hukum dalam kehidupan berbangsa dan bernegara. Tanpa adanya pendampingan hukum maka kesetaraan di hadapan hukum sebagaimana diamanatkan konstitusi dan nilai universal hak asasi manusia tersebut tidak akan pernah terpenuhi. Bantuan Hukum adalah media bagi warga negara yang tidak mampu untuk dapat mengakses keadilan sebagai manifestasi, jaminan hak-haknya secara konstitusional. Adriaan Bedner ${ }^{127}$ menjelaskan bahwa salah satu hambatan yang kerap terjadi dalam upaya memperjuangkan

${ }^{125}$ Lihat bagian Menimbang dalam Penjelasan UU No. 18 Tahun 2003, yaitu: Dalam usaha mewujudkan prinsip-prinsip negara hukum dalam kehidupan bermasyarakat dan bernegara, peran dan fungsi Advokat sebagai profesi yang bebas, mandiri dan bertanggung jawab merupakan hal yang penting, di samping lembaga peradilan dan instansi penegak hukum seperti kepolisian dan kejaksaan. Melalui jasa hukum yang diberikan, Advokat menjalankan tugas profesinya demi tegaknya keadilan berdasarkan hukum untuk kepentingan masyarakat pencari keadilan, termasuk usaha memberdayakan masyarakat dalam menyadari hak-hak fundamental mereka di depan hukum. Advokat sebagai salah satu unsur sistem peradilan merupakan salah satu pilar dalam menegakkan supremasi hukum dan hak asasi manusia.

${ }^{126}$ Ciri-ciri negara hukum materiil pernah dirumuskan dalam International Commission of Jurists sebagai berikut:

1.perlindungan konstitusional, artinya selain menjamin hak individu konstitusi juga harus menentukan cara prosedural untuk memperoleh perlindungan atas hak-hak yang dijamin;

2.adanya badan kehakiman yang bebas dan tidak memihak;

3. adanya pemilihan umum yang bebas;

4.adanya kebebasan menyatakan pendapat;

5.adanya kebebasan berserikat /berorganisasi dan beroposisi; dan

6.adanya pendidikan kewarganegaraan.

127 Adriaan Bedner dalam Akses terhadap Keadilan: Perjuangan Masyarakat Miskin dan Kurang Beruntung untuk Menuntut Hak di Indonesia, (Jakarta: Penerbit HuMa-Jakarta, Van Vollenhoven Institute-Leiden, KITLV-Jakarta, Epistema Institute-Jakarta), hlm. 91. 
akses terhadap keadilan adalah persolan relasi kekuasaan. Dengan demikian hubungan yang imparsial dan sehat antara hakim dan bantuan hukum sangat berpengaruh dalam tegaknya hak asasi manusia tersebut, sehingga tidak lagi muncul kasus-kasus yang melangkahi hak asasi manusia ${ }^{128}$, seperti adanya kasus suap dari pemberi bantuan hukum pada hakim ${ }^{129}$.

Pasca terjadinya reformasi, pergerakan HAM dalam masa transisi tersebut mengalami kemajuan, khususnya muncul beberapa perubahan dan pembentukan instrumen hukum yang memberikan kepastian akan tegaknya HAM di Indonesia. Perubahan-perubahan tersebut bukan hanya perubahan redaksional, melainkan menyangkut pula perubahan paradigma pemikiran yang sangat mendasar. Karena itu, segera setelah agenda constitusional reform (pembaharuan konstitusi), kita perlu melanjutkan dengan agenda legal reform (pembentukan dan pembaharuan hukum) yang juga besarbesaran. ${ }^{130}$ Pembaharuan hukum juga dibarengi dengan penegakanpenegakan hukum oleh organ-organ negara untuk menjamin perlindungan dan penegakan HAM. Terbentuknya organ-organ negara sebagai titik tolak prospek penegakan HAM diantaranya: a. Pengadilan Hak Asasi Manusia , b. Komisi Nasional Hak Asasi Manusia (KOMNAS HAM), c. Mahkamah Konstitusi. Pengadilan HAM pada pembentukannya di sah kan dalam UU No. 26 Tahun 2000 Tentang Pengadilan HAM memiliki kewenangan melakukan pengadilan terhadap kejahatan genosida dan kejahatan kemanusiaan ${ }^{131}$.

Di samping penanganan peradilan HAM, keberadaan KOMNAS HAM merupakan lembaga yang menangani pengajian, penelitian, penyuluhan, pemantauan, dan mediasi hak asasi manusia (HAM) ${ }^{132}$. Di samping itu memperhatikan bahwa keberadaan Mahkamah Konstitusi sebagai penjaga marwah konstitusi, yang memuat perlindungan HAM. (pengajuan judicial review) juga dalam rangka melakukan perlindungan HAM, Moh. Mahfud MD memberikan alasan mengapa judicial review penting bagi menjaga konsistensi agar tetap pada rel konstitusi (politik konstitusi), karena hukum merupakan produk politik sehingga oleh

${ }^{128}$ Data yang dikeluarkan Lembaga Ombudsman Republik Indonesia tahun 2014 menunjukan bahwa Lembaga Peradilan mendapatkan laporan maladministrasi sebanyak 235 laporan.

129 Seperti dalam kasus hakim Nuril Huda yang terbukti menerima uang dari advokat. Hukuman non palu dijatuhkan setelah Majelis Kehormatan Hakim (MKH) menyatakan Nuril terbukti menerima uang Rp20 juta dari seorang advokat yang perkaranya disidangkan oleh Nuril. Lihat https://nakimsanwirja.wordpress.com/2014/01/06/inilah-6hakim-pelanggar-kode-etik-sepanjang-tahun-2013/ diakses pada 9 April 2015, pkl 15:07 WIB.

130 Jimly Asshiddiqie, Menuju Negara Hukum yang Demokratis, (Jakarta: PT Bhuana Ilmu Populer Kelompok Gramedia, 2009), hlm. 7-8.

${ }^{131}$ Lihat Pasal 8 dan 9 UU No. 26 Tahun 2000.

${ }^{132}$ Lihat Pasal 1 ayat (7) UU No. 39 Tahun 1999. 
karenanya bisa saja UU berisi hal-hal yang bertentangan dengan UUD atau Konstitusi. ${ }^{133}$ Selain pembentukan organ-organ negara, mengutip pendapat Friedmann mengenai sistem hukum terdiri dari tiga unsur, yakni struktur, substansi dan kultur sehingga mampu melakukan perubahan paradigma baik pada masyarakat maupun penegakan hukum. Prospek untuk menegakkan HAM merupakan prospek jangka panjang terlebih pada negara yang mengalami fase kelam sebelum perubahan ke arah demokratis. Dikatakan Moh. Kusnardi dan Harmaily Ibrahim, persoalan hak-hak asasi adalah persoalan antara individu yang memegang kekuasaan dan individu dan individu yang tidak memunyai kekuasaan ${ }^{134}$. Sebagaimana petuah O'Donnel dan Schmitter ${ }^{135}$ yang dikutip Ifdhal Kasim yang menyatakan:

"Sukar untuk membayangkan bagaimana suatu masyarakat dapat berfungsi sampai suatu tingkat yang akan menghasilkan dukungan sosial dan ideologis bagi demokrasi politik jika tidak disertai dengan keberanian menyelesaikan bagian-bagian yang paling menyakitkan di masa lalu. Dengan menolak berkonfrontasi dan membebaskan diri dari kekuatan-kekuatan dan kebencian paling dalam, suatu masyarakat tidak hanya menguburkan masa lalunya, tetapi juga nilai-nilai etis paling dasar yang mereka butuhkan untuk menciptakan masa depan yang bergairah".

Anomali kekuasaan dan pelanggaran HAM terhadap individu menjadi terulang, ketika kekuasaan pemerintah dalam kurun waktu 2004-2014 khususnya janji kepala Negara yang kemudian tidak mampu mengungkap pelangaran HAM masa lalu ${ }^{136}$.

\section{Penutup \\ 1. Simpulan}

Dalam rangka perlindungan dan penegakan HAM oleh lembagalembaga negara di antara dilaksanakan oleh: Komisi Nasional Hak Asasi Manusia (Komnas HAM), Komisi Perlindungan Anak Indonesia (KPAI), Komisi Nasional Perempuan (Komnas Perempuan), Komisi Kebenaran dan

133 Martitah, Mahkamah Konstitusi Dari Negative Legislature ke Positive Legislature, (Jakarta: Konstitusi Press, 2013), hlm. 7 - 8.

134 Jimly Asshiddiqqie, Pengantar Ilmu Hukum Tata Negara, (Jakarta: Sekretariat Jendral dan Kepaniteraan Mahkamah Konstitusi, 2006) hlm. 102.

${ }^{135}$ Rhona K.M. Smith, et al., Hukum dan Asasi Manusia, (Yogyakarta: Pusat Studi Hak Asasi Manusia Universitas Islam Indonesia, 2008), hlm. 390.

${ }^{136}$ A. pada 26 Maret 2008 di Istana Negara, ketika itu presiden menerima perwakilan korban kasus Trisakti dan Semanggi, Tanjung Priok 1984, Talangsari Lampung 1989, peristiwa Mei 1998 serta penculikan aktivis 1997 -1998. Dalam pertemuan itu, presiden berjanji akan memprioritaskan penyelesaian kasus pelanggaran HAM berat masa lalu. B. Janji kedua, terkait kasus pembunuhan Alm. Munir Said Thalib. c. terkait dialog konstruktif untuk Papua. D. pembaruan agraria (reforma agraria) 
Rekonsiliasi (KKR), namun dalam perkembangannya KKR justru dibubarkan karena tidak sesuai dengan fungsi dan tugasnya yang sesungguhnya sehingga tidak memberikan keadilan pada masyarakat. Selain dilakukan oleh Komisi yang dibentuk oleh Negara, perlindungan dan penegakan HAM saat ini lebih banyak dilakukan oleh lembaga peradilan, khususnya pasca reformasi. Diantaranya yaitu: Pengadilan HAM khusus peradilan HAM berat dan Mahkamah Konstitusi (MK) yang memiliki kewenangan menguji UU atas UUD 1945. Dalam perkembangannya justru MK lebih banyak melakukan perlindungan dan penegakan HAM pada warga Negara dengan banyaknya putusan-putusan terhadap undang-undang yang inkonstitusional, dan putusan MK pun bernilai strategis dan mampu menegakkan HAM bagi warga Negara. Esensi perlindungan dan penegakan HAM tersebut sangat dipengaruhi kedudukan hakim dalam memutus perkara, sehingga hakim memiliki peran dalam menegakkan independensi dan imparsialitas baik sebagai institusi maupun sebagai individu. Selain itu faktor lainnya adalah adanya hak mendapat bantuan hukum, pola penegakan keadilan telah menunjukkan bahwa hak untuk mendapatkan bantuan hukum adalah upaya adanya persamaan dalam hukum sebagai bagian dari pemenuhan akan hak asasi manusia.

\section{Saran}

Berdasarkan kesimpulan di atas, maka penulis dapat memberikan saran sebagai berikut: Perkembangan terakhir yang menunjukkan peran lembaga-lembaga peradilan telah menunjukkan kearah penegakan keadilan dan HAM. Sehingga peran lembaga peradilan sangat diharapkan sebagai penegak dan pelindung bagi terlanggarnya HAM warga negara. Aspek imparsial dan independensi hakim sebagai individu maupun institusi haruslah dijaga dan ditingkatkan, namun disisi lain tidak menjadikan lembaga peradilan sebagai lembaga yang superbody. Jika demikian justru akan membuka lebar akses terlanggarnya penegakan dan perlindungan HAM. Di samping itu, pemberian bantuan hukum pada warga negara tentulah merupakan hak-hak warga negara yang merupakan bagian dari HAM, dan kepastian akan persamaan di depan hukum akan terlaksana. Imparsial dan independensi antara dua elemen ini sangat menentukan penegakan HAM tersebut. 


\section{Daftar Pustaka}

\section{A. Buku}

Arinanto, Satya, 2008, Hak Asasi Manusia Dalam Transisi Politik di Indonesia. Jakarta: Pusat Studi Hukum Tata Negara Fakultas Hukum Universitas Indonesia.

Asshiddiqie, Jimly, 2005, Konstitusi dan Konstitualisme Indonesia. Jakarta: Konstitusi Press. , Jimly, 2009, Menuju Negara Hukum yang Demokratis. Jakarta: PT Bhuana Ilmu Populer. , Jimly, 2007, Pokok-Pokok Hukum Tata Negara Indonesia Pasca Reformasi. Jakarta: PT Bhuana Ilmu Populer. Jimly, 2006, Pengantar Ilmu Hukum Tata Negara. Jakarta: Sekretariat Jendral dan Kepaniteraan Mahkamah Konstitusi. , Jimly, 2010, Konstitusi Ekonomi. Jakarta: PT Kompas Media Nusantara.

Djohansyah, J., 2008, Reformasi Mahkamah Agung Menuju Independensi Kekuasaan Kehakiman, Jakarta: Kesaint Blanc.

M. Zen, A.Patra, 2005, Tak Ada hak Asasi yang Diberi. Jakarta: Yayasan YLBHI.

Martitah, 2013, Mahkamah Konstitusi Dari Negative Legislature ke Positive Legislature. Jakarta: Konstitusi Press.

Nurtjahjo, Hendra dan Fokky Fuad, 2010, Legal Standing Kesatuan Masyarakat Hukum Adat Dalam Berperkara di Mahkamah Konstitusi. Jakarta: Salemba Humanika.

Rhona K.M. Smith, et al., 2008, Hukum dan Asasi Manusia. Yogyakarta: Pusat Studi Hak Asasi Manusia Universitas Islam Indonesia.

Suny, Ismail, 1978, Pembagian Kekuasaan Negara. Jakarta: Aksara baru.

Syahuri, Taufiqurrohman, 2011, Tafsir Konstitusi Berbagai Aspek Hukum. Jakarta: Kencana Prenada Media Group.

W. Nickel, James, 1996, Hak Asasi Manusia, Making Sense of Human Rights. Jakarta: PT Gramedia Pustaka Utama.

Widodo, J. Pajar, 2013 Menjadi Hakim Progresif. Bandar lampung: Indepth Publishing.

\section{B. Peraturan Perundang-undangan}

Keppres RI Nomor 129 Tahun 1998

Ketetapan MPR Nomor XVII/MPR/1998 tentang HAM

Undang-Undang No. 39 Tahun 1999 tentang HAM

Undang-Undang No. 26 Tahun 2000 tentang Pengadilan HAM

Undang-Undang No. 23 Tahun 2002 tentang Perlindungan Anak

Undang-Undang No. 18 Tahun 2003 tentang Advokat 
Undang-Undang No. 27 Tahun 2004 tentang Komisi Kebenaran dan Rekonsiliasi

Undang-Undang No.12 Tahun 2011 tentang Pembentukan Peraturan Perundang-undangan

\section{Media/Koran}

Wacana HAM, Lagi, Hasil Penyelidikan Dikembalikan, Edisi I/Tahun $\mathrm{XII} / 2014$

Siaran Pers Mahkamah Konstitusi, Warga Papua Uji Sistem Pemungutan Suara dalam Pemilu, Jakarta, 14 April 2014.

\section{Website}

www.kpai.go.id, Kompilasi Pelanggaran Hak Anak 2007-2009

\section{E. Tesis dan Disertasi}

Melani, Endang Sri Perlindungan Hak-Hak Korban Pelanggaran Hak Asasi Manusia Berat Di Timor Timur Dalam Putusan Pengadilan Ham Nomor: 02/PID.HAM/AD.HOC/2002/PN.JKT.PST, Tesis, Program Pascasarjana Fakultas Hukum Universitas Indonesia.

\section{F. Jurnal}

Baehaqi, Ja'far. Perspektif Penegakan Hukum Progresif dalam Judicial Review di Mahkamah Konstitusi, Jurnal Mahkamah Konstitusi, Volume 10 Nomor 3, September 2013.

Isra, Saldi. Peran Mahkamah Konstitusi dalam Penguatan Hak Asasi Manusia Di Indonesia, Jurnal Mahkamah Konstitusi Volume 11, Nomor 3, September 2014.

Muhtadi, 2012, Antara Penyadapan dan Perlindungan Hak Atas Informasi, (Jakarta: Jurnal Pusat Kajian Konstitusi dan Perundang-undangan Universitas Islam Indonesia). 